\title{
FDI in hot labour markets: The implications of the war for talent
}

\author{
Bettina Becker ${ }^{1}$, \\ Nigel Driffield ${ }^{2}$, \\ Sandra Lancheros ${ }^{3}$ and \\ James H. Love ${ }^{3}$ \\ ${ }^{1}$ Aston Business School, Aston University, \\ Birmingham B4 7ET, UK; ${ }^{2}$ Warwick Business \\ School, University of Warwick, Coventry CV4 7AL, \\ UK; ${ }^{3}$ Leeds University Business School, University \\ of Leeds, Leeds LS2 9JT, UK

\section{Correspondence:} \\ N Driffield, Warwick Business School, \\ University of Warwick, Coventry CV4 7AL, UK \\ e-mail: nigel.driffield@wbs.ac.uk
}

\begin{abstract}
This paper highlights an inherent contradiction that exists within investment promotion activities in rich countries. Since the financial crisis, many inward investment agencies have shifted their activities from job creation per se to seeking to attract investment in high-tech activities. Such knowledge-intensive sectors are engaged in what has become referred to as "the war for talent", so locations need to understand their value proposition to firms, especially where labour is tight. This paper explores the implications of this, in terms of the impact on employment and earnings of high skilled labour. We show that, because skill shortages already exist in many of these sectors, seeking to attract inward investment in these sectors simply causes the earnings of such workers to be bid up, and employment in the incumbent sector to fall. We highlight the over-riding importance that firms place on the availability of skilled labour when determining locations, and how policies which promote labour market flexibility, particularly through investment in skills to address skill shortages, can significantly mitigate the adverse effects, which tend to be more keenly felt in poorer regions of Europe where skilled labour is in even shorter supply. Journal of International Business Policy (2020) 3, 107-133. https://doi.org/ | 0.1 057/s422/4-020-00052-y
\end{abstract}

Keywords: inward investment; labour market flexibility; knowledge spillover

\section{INTRODUCTION}

Knowledge-intensive firms are increasingly engaged in a global war for talent, particularly in sectors related to science, technology and innovation. The extent to which leading firms experience significant skill shortages, particularly in the most senior scientific, technical and managerial positions, is an issue that has been recognised for over 20 years, following the famous McKinsey report (Chambers, Foulon, Handfield-Jones, Hankin, \& Michaels, 1998). Typically, such firms often report skill shortages, especially in key roles, from advanced manufacturing to R\&D and finance, as well as in supply chain management and marketing. Equally, it is now over 10 years since this issue was recognised in mainstream international business (IB) by Beechler and Woodward (2009).

At the same time, locations both in the West and in emerging countries are becoming ever more ferocious in their efforts to attract and retain internationally mobile investments in innovation capacity. While these initiatives to attract inward investment
Received: 18 July 2019

Revised: 16 March 2020

Accepted: 18 March 2020

Online publication date: 24 April 2020 
are perhaps more subtle than the large-scale subsidies that Western locations offered through the 1980s and 1990s, they are more holistic, sectorbased approaches that often seek to place the foreign affiliate at the heart of a network of producers, crossing locations and value chains. Many locations are chasing the same researchbased, high-tech sectors, perceived to be the engines of growth and new technology, often looking to build on existing agglomerations. As a result, most of these sectors are becoming concentrated in a limited number of locations, creating competition for skilled labour and pushing up the wages of high-skill individuals. ${ }^{1}$ What implications does this process have for the countries and regions involved, and for the policymakers charged with attracting inward foreign direct investment (FDI) and maximising its beneficial effects?

In the context of foreign investment, there is a need to develop models that explore and explain the relationships between the location of multinational firms and the availability of labour in research-intensive sectors, where competition between firms is based on innovation rather than price, and where skilled labour is a crucial element of this (Acemoglu \& Autor, 2011). Attention here needs to focus on the consequences for host economies and local firms of inward investment in sectors with overheated labour markets and skill shortages. To the best of our knowledge, there has not been a systematic investigation into this issue. This is despite its obvious importance, as governments from around the world continue to seek to attract inward investment, seemingly motivated by the perception of an entirely positive FDI effect, without considering potential adverse labour market effects for the local economy.

When considering the impact of inward FDI on host countries, the bulk of the IB literature has mainly focussed on examining potential productivity spillovers from foreign MNEs to locally owned firms, whereas the consequences on local wages have been largely neglected. This shortcoming has been emphasized in recent international business publications (i.e. Clougherty, Gugler, Sørgard, \& Szücs, 2014; Narula, 2019; Van der Straaten, Pisani, \& Kolk, 2019; Girma, Görg, \& Kersting, 2019), which consider this omission as a highly unfortunate outcome, as decisions on wages made by multinational firms are likely to have important implications for the local markets in which they operate. The international economics literature, on the other hand, has mainly focussed on understanding the well-known wage premium paid by MNEs, rather than exploring potential spillover effects on the wages paid by local firms.

Overall, the limited empirical wage-spillover literature has been unable to present conclusive results regarding the existence and direction of such spillovers (see Gorg \& Greenaway, 2004 for a survey of the earlier literature). The recent emerging body of work in the IB literature also does not offer conclusive answers. For example, while Clougherty et al. (2014) find positive wage spillovers from foreign acquisitions to domestic firms in the US, Girma et al. (2019) find negative wage spillover effects from FDI to domestic Chinese firms. Understanding the channels through which multinational activity affects local wages is, therefore, of the utmost importance from both an academic and a public policy perspective. This paper complements the recent IB literature on wage spillovers in a number of ways. First, we explore the extent to which an increasing presence of foreign activity in high-tech sectors will push domestic wages up, generating further wage growth and crowding out employment in the domestic sector, rather than creating new employment. Unlike previous studies, which have pooled all manufacturing industries, our work focusses on high-tech industries with special labour market conditions, as discussed above. Moreover, while prior studies have examined the domestic wage effects from MNEs operating in the same region, this paper explores the role of geographical proximity between MNEs and domestic firms in determining such effects. In doing so, we differentiate the spillover effects induced by MNEs located in the same region in which a domestic firm operates, from the spillover pressures coming from MNEs located outside the region. Studying the role of this geographical proximity is particularly relevant for high-tech sectors where high-skilled workers enjoy high mobility. Also, unlike previous works, we take a more integrated approach to examine the effects of MNE in local working conditions, by studying not only the implications for local wages, but also the resulting employment effects.

More importantly, this paper contributes to the emerging IB wage-spillover literature by evaluating the moderating role of labour market flexibility and the potential to absorb technological spillovers from FDI in a given location. A growing literature exploring the importance of employment protection legislation or labour market flexibility for firms' location decisions is typically concerned 
with the extent to which local labour markets can absorb negative shocks, but the importance of flexibility in already overheated labour markets has not been explored. ${ }^{2}$ We argue that it is likely that in high-tech sectors a greater degree of labour market flexibility helps local labour markets to host foreign investors without significant wage increases or crowding out effects. Also, locations with greater capacity to absorb productivity spillovers from FDI might be more capable to mitigate the adverse labour market effects, as the earnings increase that comes with higher productivity allows local firms to retain their highly skilled workers in the face of the competition from the foreign, higher-paying, investors. In this paper we test empirically these conjectures.

While the emerging IB wage-spillover literature has examined wage-spillovers in single host economies, we take a multicountry approach by focussing on European countries, following the call by Clougherty et al. (2014) for empirical work based on European data. Europe is an ideal setting as it comprises established technology intensive markets, emerging economies seeking to upgrade technology, and variations in labour market flexibility and the potential to absorb FDI spillovers.

By considering the employment implications of FDI, our paper is also related to the well-established literature that seeks to explore the relationships between inward investment in a given location and the demand for certain types of employment, building on Barrell and Pain (1997) and Driffield and Taylor (2000). However, this literature is limited in terms of contributing to our understanding of technology intensive sectors. The literature founded in economics is essentially agnostic about the motivation for multinationals to engage in the observed FDI, relying on the assumption that inward investors have a technological advantage over local firms (Driffield, 1999). Equally, the IB literature presumes that FDI by high-tech firms into rich economies is motivated either by knowledge seeking or market seeking by technological leaders. In either case this ignores the possibility of competition for skilled workers by inward investors seeking to compete through innovation (Teixeira \& Tavares-Lehmann, 2014). This type of analysis is insufficient in a world where multinational firms increasingly choose locations on the basis of their search for different types of human capital and labour capabilities, and where specific locations, especially within the developed world compete globally for foreign investments and assets (Kafouros, Buckley, \& Clegg, 2012).

Our empirical analysis uses a large disaggregated firm-level international dataset spanning six research-intensive sectors (including chemicals, pharmaceuticals,; computers, electronics, R\&D, and other scientific activities) in 28 European countries over a 9-year period (from 2002 to 2010). We thus investigate the first decade of the recent increasingly globalised post-2000 period. In analysing a European sample, we also contribute to the overall, still mixed and inconclusive empirical, evidence on the impact of MNEs on local firms in advanced economies. This lack of clear-cut evidence has been surprisingly long-standing, established in the early review in Rodrik (1999), subsequently confirmed in Smeets (2008) and recently ascertained again in Crescenzi, Gagliardi, and Iammarino (2015). We find that the presence of foreign firms has a positive effect on domestic wages in research-intensive sectors, but that labour market flexibility and the potential to absorb FDI spillovers matter here. The wage effects are strongest in locations with less flexible labour markets and greater ability to absorb FDI spillovers, whereas these effects are more moderated (or insignificant) in locations with higher levels of labour market flexibility and/or lower capacity to absorb FDI spillovers. In terms of employment, our results provide evidence of crowding out of domestic employment by FDI in locations with low levels of labour market flexibility and less potential to absorb spillovers. These findings have implications for the firms concerned, as well as for inward investment agencies and policymakers more widely.

The remainder of the paper is organised as follows: the next section describes the conceptual framework and sets out the main hypotheses. The third section presents the data and econometric model. The empirical results are discussed in the fourth section, followed by a discussion and conclusions in the final section.

\section{CONCEPTUAL FRAMEWORK AND HYPOTHESES}

The conceptual framework that we adopt here is the one developed in the literature seeking to explore the labour market implications of inward FDI, building, for example, on Driffield (1999) and Driffield and Taylor (2000). This, along with the now seminal work of Barrell and Pain (1997), starts with a number of fundamental principles derived 
from Dunning's (1979) OLI paradigm. This literature was developed to essentially explore the implications for unskilled workers of globalisation, whether in terms of FDI or competition from imports (Machin 2003). The basic premise of this literature is that, in a given location, inward investors have higher productivity than average, and, therefore, pay higher wages (Driffield and Girma 2003). As a result of this, inward investment acts as an exogenous shock on the local labour market, generating both direct and indirect effects. The within-region effects are expressed most recently in Girma et al. (2019), who explore the implications for wages but not employment. We, therefore, seek to extend this by considering interregional effects, and the implications for employment, the most common focus of policy.

The theoretical interpretation of this is to better understand the changes in labour demand that occur as the result of inward investment. It is also informative in understanding why these will differ, and why firms' responses to this "shock" will differ. Based on the analysis of ownership advantages, assume that (as is borne out by the empirical literature) on average inward investors have higher productivity than the cohort of domestic firms. Investment thus increases the demand for the best workers, and, for a given level of labour, the foreign firm is able to offer a higher wage. Wages increase, this being led by the inward investors. Previous work, focussed on less skilled workers, has found that wages are bid up (Driffield and Taylor, 2003). In turn, domestic firms then find themselves having to respond to this increased demand for skilled labour (Driffield, 1999; Driffield \& Girma, 2003), and their wages are bid up. In the absence of productivity spillovers, therefore, domestic firms find that, as wages increase, they can afford less labour.

Building on this framework, our first hypothesis develops these arguments in the context of hightech sectors. Competition in high-tech sectors is driven by ownership advantages, either in terms of the strategy of exploiting these advantages in new locations, or by the need to augment them through knowledge sourcing and the appropriation of spillovers. The interaction, therefore, between ownership advantages and location advantages drive both FDI decisions, but equally importantly what types of activities firms choose in given locations. Our starting point, therefore, for understanding the likely effects of inward investment on local labour markets is how these ownership advantages translate into labour demand. Exploiting ownership advantages in new markets results in technology transfer across international boundaries, but initially within the multinational firm (Smeets, 2008). This intra-firm technology transfer generates a productivity gap between foreign and local firms (Temouri, Driffield, \& Higon, 2008). This productivity gap leads to the inward investors offering higher wages in competing for domestic skilled workers, and then causes a disequilibrium in domestic firms, where wages rise beyond hitherto sustainable levels. The thus squeezed local firm (Cao \& Mukherjee, 2013) is, therefore, faced with a choice between paying the higher wages and reducing employment, or alternatively paying the higher wages while maintaining the same employment levels, and hence accepting lower profits, in terms of a shift in rents away from the firm and to skilled employees, at least as far as this is possible while maintaining above-zero profits.

However, at the same time, there is also the possibility of local firms catching up with inward investors by increasing productivity. The mechanisms for this - including direct technology transfer along supply chains, formal sharing of technology, increased competition, and spillovers through informal channels and labour mobility are discussed in detail in Caves (1996) and Driffield (2001). Extending this, Driffield and Love (2007) also point out that there is need within this framework to consider both spillover effects and other motivations for FDI, such as (in the case of research-intensive sectors) technology-sourcing FDI. Firms which seek to engage in technologysourcing FDI may still generate increased competition for labour, but, as Driffield and Love (2007) demonstrate, produce no spillover effects. Extending this analysis to the labour market effect, this would be characterised by an increase in demand for skilled workers, but without any overall productivity increase. In the manner suggested by Taylor and Driffield (2005) or Driffield and Girma (2003), this leads to an increase in earnings of skilled workers in the host economy, and a relative decline in demand for unskilled workers (Barrell \& Pain, 1997). Inward investment can crowd out domestic employment, either directly by competing for the same scarce labour resources or indirectly through bidding up wages in already overheated labour markets. The direct effect, as outlined in Barrell and Pain (1997), comprises an increase in the demand for skilled labour through an exogenous increase in skill-augmenting capital. 
These relative effects then become an empirical question. Similar analysis based on product market competition (see, e.g., Aitken, Harrison, Lipsey, 1996, or Markusen \& Venables, 1999) allows for market conditions, for example in terms of the degree of competition in the market, or related institutions. This leads to our first hypothesis:

Hypothesis 1: The increased demand for skilled labour arising from FDI by foreign-owned firms crowds out domestic employment of skilled workers in research-intensive sectors.

We subsequently turn to the relative magnitudes of these effects. First, is the nature of the labour demand function. If firms' profitability is high perhaps because they face little competition - then labour demand curves will be steep, and firms will be able to absorb the wage increase with a smaller, or no, reduction in labour, or pass it on to consumers. Second, the nature of the labour supply is also important. Much of the extant empirical analysis described above was carried out on unskilled workers (for a discussion of the early literature, see Driffield \& Taylor, 2000). This tends to start with the premise that, for many types of unskilled labour, there is excess supply, so no need, for example, for firms to pay higher wages in response to the FDI shock, though of course, even with what may be termed "unskilled" sectors, firms will still seek to retain their better employees. In considering the domestic firms' responses to the shock, one must consider two issues. Firstly, how flexible labour markets are: how easy firms find it for example to adjust employment numbers, the extent to which wages are regulated, or differentials between activities must be protected. Secondly, the scale and scope of productivity spillovers. If firms are able to benefit in terms of productivity increases resulting from the inward investment, then this productivity growth may offset the dampening impact of any wage increase on employment. The extent to which these relative effects will be realised is, of course, an empirical question.

As we explore above, the empirical literature in this area has focussed largely on unskilled workers, although some analysis has focussed on differences between skilled and unskilled sectors (Driffield \& Girma, 2003; Driffield \& Taylor, 2006). However, while one can see high-skilled labour in the same light, a number of additional considerations are required. Firstly, as we outlined above, skilled labour, especially in high-tech sectors, is already scarce, and thus subject to high levels of wage inflation. Secondly, skilled workers are more mobile, and, due to higher returns, willing to travel further. Inter-regional wage spillovers tend to be greater for skilled workers (Driffield \& Taylor, 2000, 2006) due to greater levels of mobility. In turn, labour mobility is a key element of labour market flexibility, to which we return below.

In addition to illustrating the framework for our study, this also allows us to consider several policy responses to this particular problem. Firstly, as we outline above, many locations around the world are chasing the same types of investment, which has the potential simply to increase competition for already scarce types of labour, and emphasises the need for regions to attract good quality labour, through more general policies around housing, schools and infrastructure. Secondly, both national and regional government should emphasise skills provision and training, thus increasing the pool of skilled labour. Thirdly, policies are required to encourage innovation and spillovers, thus maximising the benefits of inward investment rather than the detrimental effects on firms. Finally, our framework emphasises the importance of labour market flexibility. Labour mobility is key here, and the ability of firms to respond to changes in demand, as well as recognising different types of employment, augment each other. While high-tech firms require high-skill labour, they also require other types of labour to augment the skilled labour. In turn, this links to discussions relating to differences in national labour market policy, and to the type of economy that underpins that policy. These issues are typically explored in the context of IB using the concepts of both institutions as sources of location advantage, but more importantly in crosscountry studies, the literature on varieties of capitalism. We discuss this in more detail in the motivation of hypothesis 3 below.

\section{The Role of Absorptive Capacity}

There is a now a large literature which has sought to examine the impacts of inward investment on a given location in general terms, but with an emphasis of employment effects, and the direct and indirect impact on productivity. This large empirical literature owes its genesis to Caves (1996), who explores the direct effects of technology transfer from the MNE to domestic firms, the so-called 'batting average' effect, as well as the indirect effects that occur through technology or productivity spillovers. FDI that is motivated by the 
MNE's desire to exploit its technological advantages in new markets requires technology transfer from the MNE's headquarters abroad to the affiliate in the host country (Driffield, Love, \& Taylor, 2010), and this occurs either at the time of the investment or subsequently (Meyer \& Sinani, 2009). Our starting point, therefore, is the literature developed from Girma, Greenaway, \& Wakelin (2001) and Driffield (1999), based around ownership advantages developed in the MNE's home country and facilitating internationalisation through FDI.

The extent to which domestic firms benefit from increased productivity through spillovers from the MNE as a consequence of its FDI will influence the domestic firms' ability both to absorb higher wages costs and to compete with foreign firms for key workers. This builds on an earlier analysis by Driffield and Girma (2003), who examine the drivers of wage spillovers in the UK. They find that, as foreign investment drives up the demand for skilled labour, wage spillovers are much larger in the presence of productivity spillovers, as productivity growth is required for firms to meet higher labour costs. Thus, one needs to examine the labour market effects of inward investment alongside the wider spillovers or technology transfer literature (Driffield, Love, \& Taylor, 2009).

In a comprehensive meta-analysis of nearly 70 empirical studies testing for spillovers from foreign investment, Meyer and Sinani (2009) show that the host country level of development plays a crucial role in moderating the ability of local firms to absorb and react to foreign technology. They show that local firms' absorptive capacity is "closely associated with the level of income in the economy, which provides firms with the financial resources to acquire complementary resources, and to pay wages that match foreign investor's wages, and thus to benefit from attracting and retaining skilled employees" (p. 1078). ${ }^{1}$ Building on this, we posit that domestic firms in researchintensive sectors, particularly those in richer countries, will have higher levels of absorptive capacity and are, therefore, more likely both to attract the most technologically advanced inward investment and to absorb any resulting technology or productivity spillovers. The general principle is that, given the average productivity gap between inward investors and domestic firms, the greater the absorptive capacity, the greater the level of spillovers (see also Girma, 1996). Mechanisms through which these spillovers occur include technological learning and the development of innovative activities, which are highly relevant in research-intensive sectors reliant on skilled labour.

Extending this further, we build on the established FDI spillovers literature which relies on theories concerning inter-firm relationships, whether formal or informal, as well as demonstration effects as mechanisms through which technology or productivity spillovers occur. These mechanisms are typically limited to activity within close geographic proximity of the domestic firm, based on agglomeration economies and co-location effects. In contrast, FDI effects in labour markets are based on competition, and are sector-based with national effects. This leads us to conclude that, in isolating productivity spillover effects from spillovers in terms of wage and employment effects, it is necessary to distinguish between FDI within the domestic firm's region and FDI that takes place elsewhere in the country, that is, nationally rather than regionally. So, we argue that, while productivity spillovers are more limited geographically, the spillover effects of FDI in terms of wages, and crucially the resulting crowding out of employment in host country firms, will result principally from FDI originating from outside the domestic firm's region. This, therefore, extends the analysis of Girma et al. (2019), who have found evidence of positive spillover effects in domestic wages, which increase with the strength of MNE presence within the region. We go a step further, and also examine the labour market pressures from MNEs located outside the region.

In terms of the importance of the labour market effects discussed above, particularly in terms of reductions in employment, the ability to assimilate productivity spillovers has an important moderating effect. For example, if technology transfer occurs between inward investors and domestic firms, then domestic firms may be better able to pay the higher wages that result from increased demand for skilled workers, as the firms' productivity increases. In such circumstances, we may observe even greater wage growth, but relatively more modest crowding out in terms of employment.

However, as the wider literature on spillovers recognises, ${ }^{3}$ such technology spillover effects are not automatic, and, in research-intensive sectors, many firms go to considerable lengths to protect their intellectual property. Hence, we have to consider the effects of the technologically advanced inward investment both in the presence 
or absence of such spillovers. This is related to the type of investment and the accompanying technology. FDI in developed economies is not driven simply by market-seeking motives: it is driven by the need to locate the most important parts of the global value chain where they can be most effective for the firm in generating dynamic capabilities. This in turn is driven by the need to locate technology into its most suitable location, and to attract labour to augment this process. Crescenzi, Pietrobelli, Rabellotti (2014), for example, find that regions attract more sophisticated stages of the value chains, that is high-tech (innovation and $R \& D)$ functions, insofar as their local knowledge assets and socio-institutional environment including skilled labour - contribute towards MNEs' value generation. Typically, in researchintensive sectors, as we explore above, demand for this labour is already high prior to the FDI. It is reasonable to assume, therefore, that, even in the absence of technology transfer, inward FDI in these sectors will increase the demand for skilled labour, pushing up earnings, thus causing a reduction in employment in the domestic firms. This effect will be heightened due to shortages of skilled labour in high-tech sectors.

Variation in spillover effects between host countries is discussed in the review paper by Meyer and Sinani (2009). Their analysis suggests that, controlling for factors such as firm size or sector, larger productivity (or technology) spillover effects are found in more advanced countries. Typically, the spillover literature links this to FDI motivation (Driffield and Love 2007), but our analysis here argues that this is less important, building on Cantwell and Smeets (2013), who argue that, in advanced locations, motive is less important in determining spillovers. They argue that technology-sourcing FDI still increases aggregate innovation (innovation being a necessary condition of technology-sourcing FDI), and generate agglomeration economies in such locations. Thus, different regions will demonstrate different aggregate effects, depending on whether the crowding out effect or the technology transfer effect dominates. Taking the analysis of Cantwell and Smeets (2013) and Meyer and Sinani (2009) together, this suggests that the potential for spillover effects is positively related with the host county's ability to reduce the adverse employment effects of inward investment. ${ }^{4}$ As Driffield and Girma (2003) demonstrate, such spillovers support wage increases both within and across regions. Thus, in our analysis, we classify domestic firms' countries and regions in terms of the ability to absorb spillovers.

Hypothesis 2: Locations in which domestic firms are able to absorb spillovers are better able to mitigate the adverse labour market effects of FDI.

\section{The Importance of Labour Market Institutions}

Labour market flexibility is concerned with how well countries (or regions) can withstand demand shocks, or prevent them leading to increased unemployment. This generally refers to wage flexibility, and the extent to which wages can adjust downwards to limit unemployment growth. In addition to wage flexibility, Soltwedel, Dohse, and Kreiger-Boden (1999) highlight working time flexibility and geographical mobility (generally internally within a country) as factors that may offset wage inflexibility. The issue of labour market flexibility is discussed in detail in the labour economics literature (see, e.g., Monastiriotis, 2005), as well as in the literature on wage dispersion (Taylor \& Driffield, 2005; Driffield \& Taylor, 2006). This essentially takes the view that different labour market institutions foster different degrees of flexibility, but that these institutions are themselves a product of a wider set of economic institutions and political philosophies. ${ }^{5}$ Sapir (2006), for example, develops a taxonomy for Europe that follows closely a 'varieties of capitalism' (VOC) approach familiar in IB.

In the context of linking VOC to firm-level decision-making, the core argument is that institutions generate "distinct profiles of institutional comparative advantage in production", (Witt \& Jackson, 2016, p. 798). Central to this is the argument that there exists no 'best' set of institutional arrangements, but rather institutions evolve through the democratic process, coupled with the need to underpin the set of activities that have arisen in a given country. The framework offered by VOC uses a qualitative approach to distinguishing types of market economies. Hall and Soskice (2001), for example, distinguish between liberal market economies (LMEs) and coordinated market economies (CMEs), which may, in our context be thought of as a distinction between the types of labour markets that one typically sees in AngloSaxon countries compared to the Scandinavian model.

Typically, LMEs have higher levels of labour market flexibility than CMEs, and are associated 
with higher levels of wage dispersion. Locations with more flexible labour markets not only have greater wage dispersion, increasing the returns to skills, but also a stronger correlation between earnings and productivity. In periods when labour demand declines, these locations exhibit greater wage flexibility and less reduction in employment in response to shocks. Linking this argument to the elaboration on the FDI effects above, labour market flexibility may, therefore, play a role in influencing the impacts of FDI, but has thus far been omitted from this literature.

The mechanisms by which labour market flexibility impacts on earnings and employment changes as the result of external shocks are discussed at length in Cuñat and Melitz (2012), who argue that ability of individuals to relocate, and the ability of firms to reallocate resources, through, for example, hiring and firing, are key determinants of differences in returns to labour and comparative advantage across countries. We argue that higher levels of labour market flexibility will reduce the extent to which increased labour demand resulting from inward FDI causes wages to be bid up, and, at the same time, reduce the extent to which this causes a reduction in domestic employment. So, irrespective of the extent to which technology transfer occurs, or the extent to which domestic firms are able to mitigate any increase in earnings through, for example, productivity increases, labour market flexibility is an important moderator of the labour market effects of FDI.

This leads to the next hypothesis:

Hypothesis 3: The greater the degree of a country's labour market flexibility, the lower the relative magnitudes of the earnings and employment effects of inward FDI in research-intensive sectors.

Our framework, therefore, seeks to develop the importance of labour market flexibility within the setting of the wage and employment direct and indirect labour market effects of FDI, which also improves the granularity of our analysis. However, while there are various indicators of labour market flexibility, we argue, building on the VOC literature, that it is the qualitative differences between labour markets that drive differences in labour market flexibility, and in turn determine the labour market responses to inward investment, rather than simply a difference in an index. In order, therefore, to apply the VOC approach, and to allow for labour market flexibility effects, we borrow from the Sapir $(2005,2006)$ taxonomy. This extends the VOC approach to labour market flexibility using the widely applied approach offered by Sapir (2006), ${ }^{6}$ which makes four distinctions within European labour markets, extending the VOC distinction but also allowing for the emergence of transition countries. Nölke and Vliegenthart (2009), for example, extend the traditional VOC literature to consider emerging economies, with a focus on the CEE countries. As they outline, the nature of the emerging institutions in the CEE countries does not naturally map onto the LME/ CME distinction discussed above, but rather they identify a distinct nature of capitalism within those countries. A similar point was made more recently by Drahokoupil and Myant (2015), who argue that one also has to consider the essential VOC typology against measures of economic performance. We argue, therefore, that, while these authors seek to justify the classification of a third group within the VOC literature, one also needs to consider the differences between northern European and Mediterranean countries. This is indeed what Sapir (2006, 2014) advocated. This influential report, and its subsequent retrospective, considers EU labour market institutions, and in turn labour market flexibility, as falling into four distinct groups: Nordic, Anglo Saxon, Continental and Mediterranean. Mediterranean countries have generally high levels of labour market protection and high levels of labour market segmentation, while the Nordic model is characterised by high levels of social protection and welfare provision. These exist alongside the Anglo-Saxon countries, now characterised by weak unions and high levels of wage dispersion. Finally, the continental countries, such as Belgium, Germany and France, differ from these through stronger unions with high levels of collective bargaining, and relatively high levels of labour market segmentation. As we focus on all of Europe rather than the EU15 as Sapir (2005) did, we amend his classification by merging the Nordic and AngloSaxon countries, ${ }^{7}$ and introducing the group of transition or accession countries, building on Sapir's (2014) update, as indicated in Table A1 in appendix A.

\section{The Integrative Conceptual Framework: Labour Market Flexibility, Absorptive Capacity and FDI Effects in Research-Intensive Labour Markets}

Seen through the lens of the research-intensive sectors, in considering the labour market effects of 
FDI, the framework outlined above offers insight to policy-makers in terms of the sectors that they may prioritise in terms of attracting inward investment. Investment promotion agencies at a local or regional level typically have two objectives that in a sense may be seen as competing with each other rather than being complementary. Typically, in developed regions, investment promotion agencies have an objective not only to generate employment but also to operate within the framework of more general industrial policy or business support infrastructure to improve innovation and productivity. One may consider that increases in productivity and employment by definition may be in contradiction with each other, but the framework, suitably supported by empirical evidence, offers an understanding of the relative elasticities of these effects for different types of sectors and labour markets.

Building on the discussion of the Sapir typology discussed above, Fig. 1 illustrates this with reference to our country groupings, dividing countries according to their labour market flexibility and absorptive capacity and the expected labour market effects from FDI in each case. We argue that 'traditional' spillovers, in the form of productivity gains, mitigate the crowding out effects: productivity growth facilitates earnings increases and thus helps firms to retain their key workers (Hypothesis 2 ). At the same time, labour market flexibility increases the ability of a local labour market to absorb new investment without it leading to significant wage increases or reductions in employment (Hypothesis 3).

\section{DATA AND ECONOMETRIC MODEL}

\section{Data}

We perform our analysis using a cross-country firmlevel dataset for the period 2002-2010. The dataset is drawn from the ORBIS database published by Bureau van Dijk. We focus specifically on a number of research-intensive sectors across a range of 28 European countries. We classify these countries according to their degree of labour market flexibility, following Sapir's (2005) taxonomy, as described in Table A1 in Appendix A. ${ }^{8}$ As discussed in the introduction and the conceptual framework sections above, the European context of our analysis is interesting and important due to the lack of clearcut empirical evidence on advanced economies and, more specifically, with respect to the institutional context of labour market flexibility. Moreover, the European Union plus Norway is the second-largest single market in the world, with free movement of labour and free trade, while substantial heterogeneities remain both at the national and regional levels. These include the availability of skilled labour, innovation capacity, and the amount of FDI that these countries attract.

The ORBIS database contains all firms in a country except microfirms. ${ }^{9}$ Despite some limitations common to any administrative database, the ORBIS database is one of the most suitable IB microdatabases to perform our empirical analysis, as it
Figure 1 Full integrative conceptual framework.
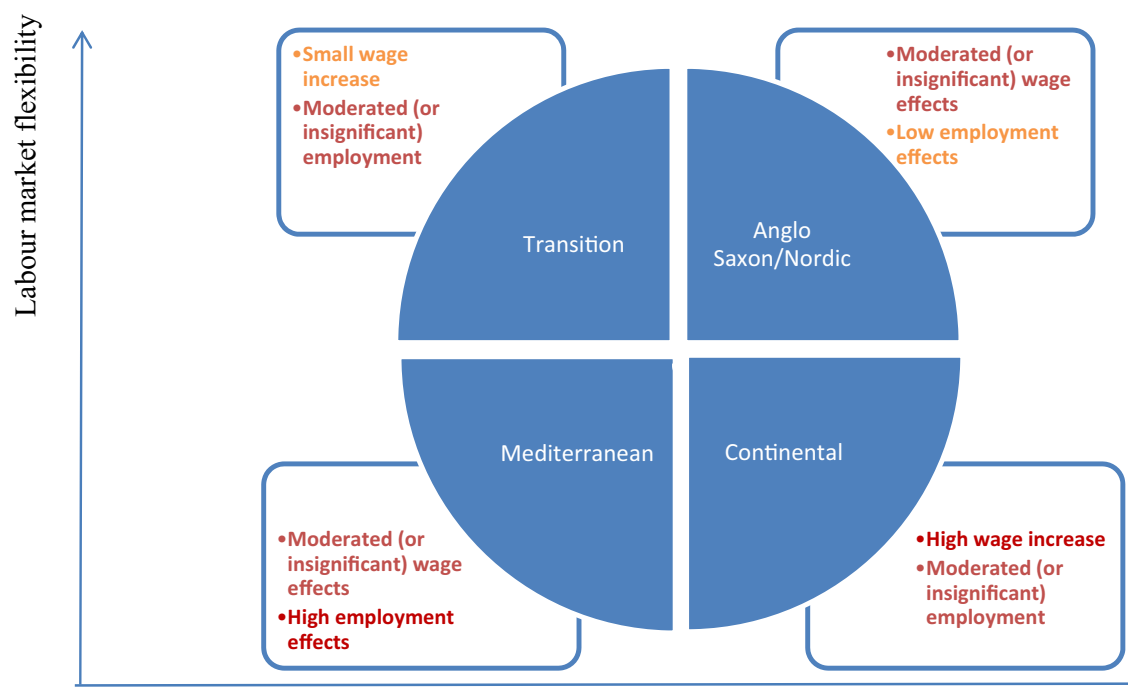

Capacity to absorb Spilliovers 
Table 1 Number of observations by group of countries and years.

\begin{tabular}{lllll}
\hline Year & Nordic and Anglo-Saxon countries & Continental countries & Mediterranean countries & Transition countries \\
\hline 2002 & 8,031 & 5,501 & 15,873 & 4,828 \\
2003 & 8,454 & 6,917 & 15,586 & 7,444 \\
2004 & 8,455 & 8,367 & 14,230 & 9,522 \\
2005 & 8,197 & 9,003 & 15,239 & 10,884 \\
2006 & 8,634 & 9,630 & 22,314 & 11,902 \\
2007 & 10,434 & 9,960 & 23,275 & 15,698 \\
2008 & 10,378 & 9,771 & 28,717 & 13,666 \\
2009 & 10,093 & 9,642 & 27,204 & 17,506 \\
2010 & 11,476 & 10,961 & 23,513 & 14,320 \\
\hline
\end{tabular}

Table 2 Number of observations by industry and year.

\begin{tabular}{|c|c|c|c|c|c|c|c|c|c|}
\hline Industry (NACE rev. 2) & 2002 & 2003 & 2004 & 2005 & 2006 & 2007 & 2008 & 2010 & 2011 \\
\hline 20 & 6,696 & 7,134 & 7189 & 7,534 & 8,980 & 9,616 & 9,803 & 9,832 & 9,258 \\
\hline 21 & 1,217 & 1,292 & 1,366 & 1,491 & 1,746 & 1,908 & 1,916 & 1,951 & 1,872 \\
\hline 26 & 6,008 & 6,506 & 6,559 & 6,861 & 8,233 & 9,561 & 9,640 & 9,895 & 9,116 \\
\hline 27 & 6,214 & 6,724 & 6,426 & 6,753 & 8,588 & 9,715 & 10,050 & 10,103 & 9,453 \\
\hline 72 & 2,447 & 2,777 & 3,065 & 3,421 & 4,105 & 4,889 & 5,127 & 5,605 & 5,256 \\
\hline 74 & 11,651 & 13,968 & 15,969 & 17,263 & 20,828 & 23,678 & 25,996 & 27,059 & 25,315 \\
\hline
\end{tabular}

Industry description (NACE rev. 2): 20 manufacture of chemicals and chemical products; 21 manufacture of basic pharmaceutical products and pharmaceutical preparations; 26 manufacture of computer, electronic and optical products; 27 manufacture of electrical equipment; 72 scientific research and development; 74 other professional, scientific and technical activities

allows us to account not only for firm-level heterogeneity but also for differences across different geographical units, industries, and institutional backgrounds. The coverage provided by ORBIS compared with say official data is discussed in detail by Ribeiro, Menghinello, and Backer (2010). ${ }^{10}$ We include all firms to ensure that our sample is representative of both countries and industries within the countries. We restrict our analysis to regions/sectors which have some foreign presence $^{11}$ in order to remove the possibility of over-stating the effect due to selection bias. The distribution of observations across groups of countries and years is presented in Table 1. Our six research-intensive sectors are high-tech industries at the 2-digit level as per the NACE Revision 2 sectoral classification, which we disaggregate to the 4-digit level in our empirical analysis. We use four manufacturing industries and two services industries in our analysis, as described in Table $2 .^{12}$

These high-tech sectors have the highest value added per head, and, based on Eurostat data, are those sectors that have seen the highest levels of wage growth since the start of this century. Typically, real earnings in these sectors have risen twice as fast as the average and are those often cited as being most beset by skill shortages, especially in the UK. The foreign investment stock in developed countries in these sectors grew some $12 \%$ faster between 1991 and 2012 than the average, and some $81 \%$ faster than for all manufacturing sectors (UNCTAD, 2013). This highlights the growing importance of these sectors in terms of FDI into developed countries over this period. Equally, when one considers the skill shortages that prevail globally in many of these sectors, it is clear that continued expansion will skew the returns in favour of skilled workers, with firms increasingly having to compete for talent globally.

By focussing on research intensive sectors, we move away from examining only manufacturing industries, as in most of the literature to date, and also consider increasingly relevant services. This is also important with regards to the increasing fragmentation of value chains. As Crescenzi et al. (2014), for instance, argue, and as we have laid out in our "Introduction", MNE's location decisions are no longer confined to production plants, but in addition increasingly include, for example, service functions, from technology sourcing and R\&D to distribution and marketing. 
Table 3 Summary statistics.

\begin{tabular}{|c|c|c|}
\hline & Mean & Standard deviation \\
\hline \multicolumn{3}{|l|}{ Domestic firms } \\
\hline Mean labour cost (in logs) & 3.12 & 1.22 \\
\hline Employment (in logs) & 1.95 & 1.55 \\
\hline Mean labour cost (annual growth rate \%) & 4.56 & 50.0 \\
\hline Employment (annual growth rate \%) & 1.07 & 38.3 \\
\hline Sales (in logs) & 6.55 & 2.12 \\
\hline Age & 14.8 & 13.4 \\
\hline Profitability & 4.28 & 18.2 \\
\hline Cash flow & 0.08 & 0.19 \\
\hline Market share & 0.03 & 0.10 \\
\hline Fixed assets (in logs) & 4.68 & 2.59 \\
\hline \multicolumn{3}{|l|}{ Foreign sales within the region (growth rate \%) } \\
\hline Nordic/Anglo-Saxon countries & 0.52 & 13.3 \\
\hline Continental countries & 1.22 & 18.1 \\
\hline Mediterranean countries & 3.69 & 30.6 \\
\hline Transition countries & 2.20 & 28.4 \\
\hline \multicolumn{3}{|l|}{ Foreign sales outside the region (growth rate \%) } \\
\hline Nordic/Anglo-Saxon countries & 0.73 & 9.86 \\
\hline Continental countries & 0.84 & 11.5 \\
\hline Mediterranean countries & 3.21 & 21.3 \\
\hline Transition countries & 2.39 & 20.3 \\
\hline \multicolumn{3}{|l|}{ Domestic sales within the region (growth rate \%) } \\
\hline Nordic/Anglo-Saxon countries & 0.79 & 8.16 \\
\hline Continental countries & 1.17 & 19.8 \\
\hline Mediterranean countries & 2.38 & 19.5 \\
\hline Transition countries & 1.15 & 29.4 \\
\hline \multicolumn{3}{|l|}{ Domestic sales outside the region (growth rate \%) } \\
\hline Nordic/Anglo-Saxon countries & 0.68 & 10.6 \\
\hline Continental countries & 0.87 & 10.6 \\
\hline Mediterranean countries & 2.79 & 13.4 \\
\hline Transition countries & 0.93 & 44.8 \\
\hline
\end{tabular}

Table 3 reports summary statistics of the main variables used in our empirical analysis. Some points are noteworthy as, to start with, we observe a general increase in the level of foreign activity in our high-tech sectors, at both the local and national levels, especially in the Mediterranean and transition economies. This trend has been accompanied by a rise in domestic wages, which on average grew at an annual rate of nearly 5\% during 2002-2010. Domestic employment also grew but at a more modest rate of $1.1 \%$ per annum. Of course, the average figures in Table 3 hide considerable heterogeneity at the firm level. To formally evaluate the impact of foreign activity on the domestic labour markets, we now turn our attention to the discussion of the econometric model we use in our analysis.

\section{Econometric Model}

In line with the spillovers in FDI literature, we investigate the effects of foreign activity on wages and employment by regressing firm-level wages and employment on measures of foreign presence in related industries and geographical locations. To address potential endogeneity concerns, we employ state-of-the-art dynamic panel data techniques which allow us to control for unobserved heterogeneity at the firm, industry, regional and country levels, as well as potential reverse causality between our dependent variable (firm-level wages/employment) and our measure of foreign activity in the region/industry. In this way, we address one of the most urgent concerns in the FDI spillover literature, namely the need to improve the modelling methods and estimation procedures to identifying true spillover effects from FDI. As noted by Rojec and Knell (2018) and Görg and Strobl (2001), studies based on cross-sectional data are unable to address 
such endogeneity issues; therefore, there is an urgent call for panel data modelling in order to avoid overstating the spillover effects from FDI in firm-level studies.

\section{Employment effects of foreign activity}

The empirical approach that we adopt to test our hypotheses is to augment the relatively standard labour demand model that has been widely used in the literature seeking to determine the labour demand effects of inward investment, building on Barrell and Pain (1997) or more recently Girma et al. (2019). The employment equation is derived from a standard factor demand model, following the seminal work of Card (1990) and Katz and Autor (1999). The modelling, therefore, starts with an employment equation, linking employment adjustments to a set of firm-level variables, as well as to inward FDI and more general indicators of activity in the sector/ region.

The basic employment equation is specified as follows:

$$
\begin{aligned}
\ln \mathrm{emp}_{i j r t}^{D}= & \beta_{0} \ln \mathrm{emp}_{i j r t-1}^{D}+\beta_{1} X_{i j r t-1}^{D}+\beta_{2} \mathrm{HH}_{j r t-1} \\
& +\sum_{g=1}^{4} \beta_{3 g}\left(F_{j r t-1} * D_{g}\right)+\sum_{g=1}^{4} \beta_{4 g}\left(F_{j r^{*} t-1} * D_{g}\right) \\
& +\sum_{g=1}^{4} \beta_{5 g}\left(D_{i j r t-1} * D_{g}\right) \\
& +\sum_{g=1}^{4} \beta_{6 g}\left(D_{i j r^{*} t-1} * D_{g}\right)+S_{t}+u_{i j r}+e_{i j r t}
\end{aligned}
$$

where $\ln \mathrm{emp}_{i j r t}^{D}$ represents the natural logarithm of employment by domestic firm $I$, in industry $j$, located in region $r$, at time $t .^{13}$ We explicitly account for firms' employment dynamics by including the natural logarithm of the employment level in the previous period, $\ln \mathrm{emp}_{i j \mathrm{rt-1}}^{D}$. The vector $X$ is a set of observed firm characteristics that affect employment, including real labour costs, size, age, profitability, cash flow, capital and market share. ${ }^{14}$ We also include the Herfindahl-Hirschman index for each industry in each region, and account for a full set of time dummies, time dummies interacted with country dummies $\left(S_{t}\right)$, and for unobserved time-invariant factors that affect employment $\left(u_{i j r}\right) .{ }^{15}$ Finally, $e_{i j r t}$, is an idiosyncratic error term.

Our main variable of interest is $F_{j t-1}$, which is a measure of foreign activity. We define this variable as the annual percentage change in total sales, for the sector and region for the previous year ${ }^{16}$ of all foreign firms located in region $r$ operating in the industry $j$. That is, this variable captures 'local', or within-region, effects of foreign activity. We also explore the geographic extend of FDI spillovers by accounting for the annual percentage change in total sales of all foreign firms operating in the industry $j$ outside region $r$ but within each country $\left(F_{j r^{*} t-1}\right)$. These are the 'national' effects of foreign activity.

To evaluate the role of countries' labour market flexibility and their absorptive capacity in moderating the employment effects of foreign activity, we interact our measures of foreign activity with dummy variables for each group of countries $\left(D_{g}\right)$ according to their labour market institutions and potential to absorb spillovers, as defined in Fig. 1 and Table A1 in Appendix A. ${ }^{17}$ Hence, consistent with the conceptual framework, we conduct regional analysis, apart from labour market flexibility which relates to national policy and which we hence analyse at the national level. ${ }^{18}$

In model (1), we also allow for the possibility that domestic firms not only compete with foreign firms for skilled labour but also with each other, with both competition and spillover effects being a feature of the extent of agglomeration. It is important, therefore, when seeking to determine the nature of the impacts of inward investment, that one also considers the impact of other domestic firms, especially in the context of research-intensive sectors with significant skill shortages. With this view, we capture the impact of domestic activity on other domestic firms by including the variable $D_{i j r-1}$, which is calculated as the annual percentage change in total sales of all domestic firms (other than firm $I$ ) located in region $r$ and operating in the sector $j$. As with foreign activity, we also allow for the possibility that domestic firms outside the region might have employment effects. So, analogously with foreign activity, we capture local, within-region, effects as well as national effects.

\section{Labour cost effects of foreign activity}

In order to examine the wage effects of foreign activity, we estimate a wage equation that is relatively standard in the literature, see, for example, Hijzen, Görg, and Hine (2005), and indeed the broader literature on globalisation and earnings, see, for example, Acemoglu (2002), building on Butcher and Card (1991). ${ }^{19}$ Our wage model also allows for the fact that the FDI-wage nexus is likely 


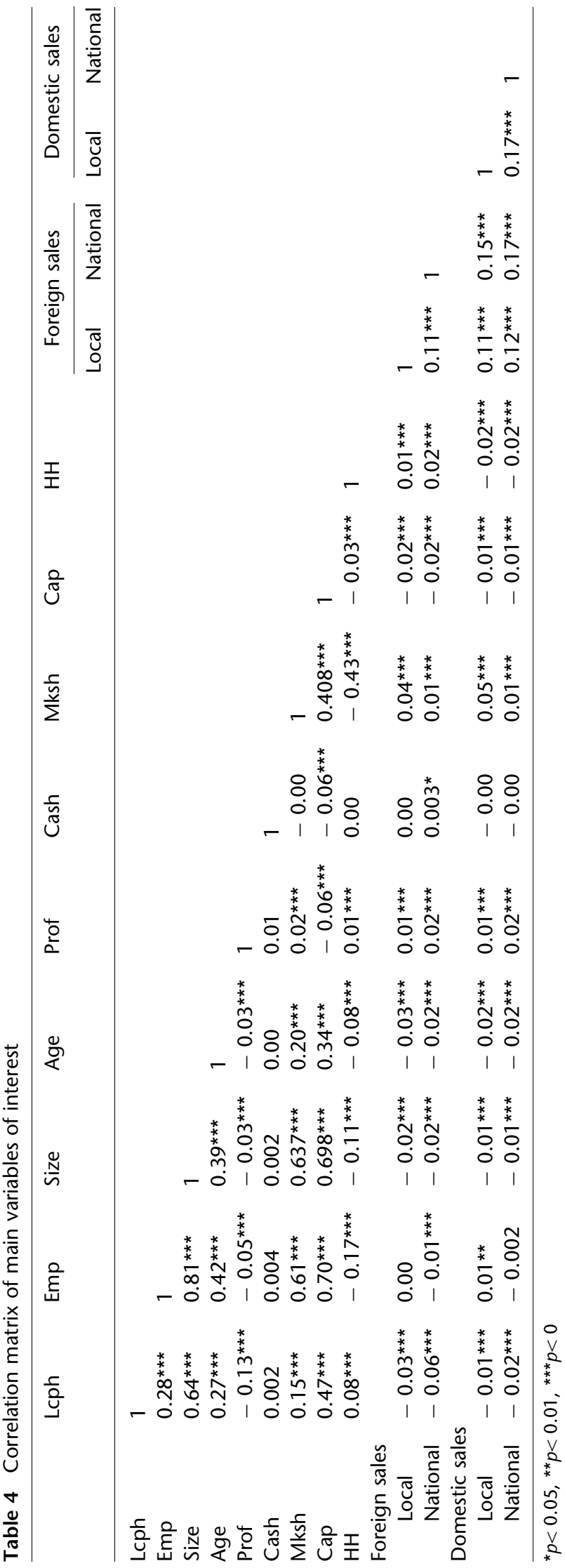

to differ for groups of countries according to their level of labour market flexibility and potential for spillovers, thus:

$$
\begin{aligned}
\ln l c p h_{i j r t}^{D}= & \alpha_{0} \ln l c p h_{i j r t-1}^{D}+\alpha_{1} X_{i j r t-1}^{D}+\alpha_{2} H H_{j r t-1} \\
& +\sum_{g=1}^{4} \alpha_{3 g}\left(F_{j r t-1} * D_{g}\right)+\sum_{g=1}^{4} \alpha_{4 g}\left(F_{j r^{*} t-1} * D_{g}\right) \\
& +\sum_{g=1}^{4} \alpha_{5 g}\left(D_{i j r t-1} * D_{g}\right)+\sum_{g=1}^{4} \alpha_{6 g}\left(D_{i j r^{*} t-1} * D_{g}\right) \\
& +S_{t}+\sum_{g=1}^{4} \alpha_{3 g}\left(F_{j r t-1} * D_{g}\right) \\
& +\sum_{g=1}^{4} \alpha_{4 g}\left(F_{j r^{*} t-1} * D_{g}\right)+\sum_{g=1}^{4} \alpha_{5 g}\left(D_{i j r t-1} * D_{g}\right) \\
& +\sum_{g=1}^{4} \alpha_{6 g}\left(D_{i j r^{*} t-1} * D_{g}\right)+S_{t}+u_{i j r}+\varepsilon_{i j r t}
\end{aligned}
$$

where $\ln l c p h_{i j r t}^{D}$ is the natural logarithm of real labour cost per head of domestic firm $I$, in industry $j$, located in a region $r$, at time $t ; \ln l c p h h_{i j t-1}^{D}$ is the natural logarithm of labour real cost per head at time $t-1$; and all other variables are defined as for Eq. (1). Correlation coefficients for key variables are shown in Table 4, indicating that multicollinearity is not a problem in our data.

Equations 1 and 2 are dynamic panel data models with fixed effects. The inclusion of a lagged dependent variable that is correlated with the error term constitutes a well-known difficulty in estimating such kind of models. These estimations are typically performed using the difference and system generalized method of moments (GMM) estimators. In this paper, we employ the system GMM dynamic panel data estimator due to Blundell and Bond (1998) to estimate our equations, as it is more efficient than the difference GMM estimator in short panels. This estimator allows us to control for the potential endogeneity of the model regressors and helps us to evaluate the dynamics of employment and wages. We use the lagged first differences of our potential endogenous regressors ${ }^{20}$ as instruments for our level equations and the lagged levels of these variables as instruments for the differenced equation. ${ }^{21}$ Only a few papers that examine MNE impact on local firms try to overcome the key limitation of sources of bias associated with timevariant omitted variables and reverse causality by going beyond static panel data, as recently also 
ascertained, for instance, by Crescenzi et al. (2015). We adopt the methodology of these contributions, in that we exploit GMM techniques to control for the potential endogeneity of employment and wages (Benfratello and Sembenelli, 2006; Driffield, 2006; Crespo, Fontoura, \& Proenca, 2009).

\section{RESULTS}

Tables 5 and 6 present tests of the hypotheses collectively. In both cases, we confirm that the GMM estimator is appropriate in this context, as the Hansen tests show the validity of the instruments and the Arellano-Bond tests indicate the absence of serial correlation in the errors.

Table 5 presents the estimation of two employment models. This starts with the baseline model estimated for the whole sample of firms in all 28 European countries. In terms of determining the effects of inward investment on overall employment, we contrast the local effects with the national effects, that is, we compare the impact of FDI in the same region as the domestic firm with the impact of FDI within the same 4-digit sector, ${ }^{22}$ but nationally. As our framework above illustrates, one may expect these to differ, as spillovers may be larger locally, but crowding out effects larger nationally, especially in sectors with significant skill shortages and a recent history of high wage growth.

Model 1 in Table 5 takes all countries together at the supra-national EU level and illustrates the aggregate effect. Our results show that, in line with our expectations, the crowding out employment effects are larger at the national than at the regional level, as illustrated by the larger negative coefficient on the national versus regional level foreign activity $(-0.001$ vs.-0.0001$)$. However, the coefficients are not significant when we look at the aggregated average effects. To better examine the employment effects of foreign activity, we evaluate the role of labour market flexibility and potential to absorb spillovers, as described in the previous section. The results from these estimations are presented in Model 2 in Table 5. Locally, spillover effects increase demand for labour following inward investment in research-intensive sectors in the Mediterranean countries, although these effects are only significant at the $10 \%$ level. However, such a positive local effect in the Mediterranean countries is offset by a substantial and highly significant crowding out national effect, where a $10 \%$ points increase in the sales of foreign firms located outside region $r$ (but within the same country) leads to a 5\% decrease in the employment of domestic firms located in region $r^{23}$

Table 6 presents the estimates of the wage equations, examining the impact of increased inward investment penetration on domestic labour costs. Here, the results are more striking. The baseline model in column 1 provides statistical evidence for increasing levels of foreign activity pushing up domestic labour costs. Our results in Model 1 indicate that a $10 \%$ points increase in foreign sales generates about $8 \%$ increase in labour cost in the domestic sector. Table 6 also offers a good deal of insight into the importance of labour market flexibility and potential for spillovers, offering support for hypothesis 3 . We find support for hypothesis 2 , in that the countries whose firms have the highest absorptive capacity, and are, therefore, likely to attract FDI that in itself generates internal productivity growth, generate wage growth in the domestic sector. The continental countries experience by far the largest wage effects from FDI, reflecting perhaps both the least flexible labour markets and the highest demand for skilled workers of all the countries in our data. However, in contrast to the Mediterranean countries, the continental countries do not experience a significant decline in employment. This result also highlights the importance of labour market flexibility at the country level. The effects for continental countries, with notoriously more inflexible labour markets, suggest that a $10 \%$ points increase in inward investment penetration will add $24 \%$ to labour costs. These results suggest a high elasticity of labour costs in response to the level of foreign activity, which our analysis suggests is consistent with the combination of both high absorptive capacity and low labour market flexibility.

Overall, it, therefore, seems that, in the interplay of (high) absorptive capacity and (low) labour market flexibility in the continental country group, the former tends to overcome the lack of moderation of employment effects of the latter, with domestic firms potentially able to catch up with the foreign investors. However, the substantive growth in labour costs may render the domestic sector uncompetitive in the long run. In the Mediterranean countries (also with inflexible labour markets, but with lower potential absorptive capacity than the Continental countries), the positive wage effects are more moderated, as predicted by our empirical framework. For this group of countries, a $10 \%$ points increase in foreign activity is associated with an 8\% increase in domestic 
Table 5 Effect of FDI on domestic employment.

\begin{tabular}{|c|c|c|}
\hline $\begin{array}{l}\text { Dependent variable: natural } \\
\text { logarithm of employment }\end{array}$ & {$[1]$} & {$[2]$} \\
\hline Employment $t-1$ & $\begin{array}{l}0.939 * * * \\
(0.0412)\end{array}$ & $\begin{array}{l}0.918^{* * *} \\
(0.0548)\end{array}$ \\
\hline Unit labour cost $t_{t-1}$ & $\begin{array}{l}-0.029 \\
(0.0645)\end{array}$ & $\begin{array}{l}-0.083 \\
(0.0707)\end{array}$ \\
\hline Size $_{t-1}$ & $\begin{array}{l}0.084^{* *} \\
(0.0375)\end{array}$ & $\begin{array}{l}0.080 \\
(0.0497)\end{array}$ \\
\hline $\operatorname{Age}_{t-1}$ & $\begin{array}{l}-0.002 \\
(0.0022)\end{array}$ & $\begin{array}{l}-0.005^{\star} \\
(0.0029)\end{array}$ \\
\hline Profitability $_{t-1}$ & $\begin{array}{l}0.006^{* * *} \\
(0.0017)\end{array}$ & $\begin{array}{l}0.003 \\
(0.0028)\end{array}$ \\
\hline Cashflow $_{t-1}$ & $\begin{array}{l}0.000 \\
(0.0001)\end{array}$ & $\begin{array}{l}-0.000 \\
(0.0002)\end{array}$ \\
\hline Market share $_{t-1}$ & $\begin{array}{l}-0.050 \\
(0.0438)\end{array}$ & $\begin{array}{l}-0.069 \\
(0.0571)\end{array}$ \\
\hline Capital $_{t-1}$ & $\begin{array}{l}-0.002 \\
(0.0097)\end{array}$ & $\begin{array}{l}0.015 \\
(0.0129)\end{array}$ \\
\hline Herfindahl $_{t-1}$ & $\begin{array}{l}-0.000 \\
(0.0000)\end{array}$ & $\begin{array}{l}-0.000 \\
(0.0000)\end{array}$ \\
\hline \multicolumn{3}{|l|}{$\begin{array}{l}\text { Foreign activity }_{t-1} \\
\quad \text { Within the region }\end{array}$} \\
\hline All countries & $\begin{array}{l}-0.0001 \\
(0.0006)\end{array}$ & \\
\hline Nordic/Anglo-Saxon countries & & $\begin{array}{l}-0.001 \\
(0.0021)\end{array}$ \\
\hline Continental countries & & $\begin{array}{l}0.002 \\
(0.0017)\end{array}$ \\
\hline Mediterranean countries & & $\begin{array}{l}0.002^{*} \\
(0.0011)\end{array}$ \\
\hline Transition countries & & $\begin{array}{l}0.003 \\
(0.0023)\end{array}$ \\
\hline \multicolumn{3}{|l|}{ Outside the region } \\
\hline All countries & $\begin{array}{l}-0.001 \\
(0.0007)\end{array}$ & \\
\hline Nordic/Anglo-Saxon countries & & $\begin{array}{l}-0.006 \\
(0.0045)\end{array}$ \\
\hline Continental countries & & $\begin{array}{l}0.005 \\
(0.0062)\end{array}$ \\
\hline Mediterranean countries & & $\begin{array}{l}-0.005^{* * *} \\
(0.0013)\end{array}$ \\
\hline Transition countries & & $\begin{array}{l}0.002 \\
(0.0027)\end{array}$ \\
\hline \multicolumn{3}{|l|}{ Domestic activity $_{\mathrm{t}-1}$} \\
\hline All countries & $\begin{array}{l}-0.002^{\star *} \\
(0.0010)\end{array}$ & \\
\hline Nordic/Anglo-Saxon countries & & $\begin{array}{l}-0.001 \\
(0.0046)\end{array}$ \\
\hline Continental countries & & $\begin{array}{l}0.000 \\
(0.0025)\end{array}$ \\
\hline Mediterranean countries & & $\begin{array}{l}0.001 \\
(0.0025)\end{array}$ \\
\hline Transition countries & & $\begin{array}{l}-0.003^{*} \\
(0.0017)\end{array}$ \\
\hline Outside the region & & \\
\hline
\end{tabular}

Table 5 (Continued)

\begin{tabular}{lll}
\hline $\begin{array}{l}\text { Dependent variable: natural } \\
\text { logarithm of employment }\end{array}$ & {$[1]$} & {$[2]$} \\
\hline \multicolumn{1}{c}{ All countries } & $\begin{array}{l}0.002^{* *} \\
(0.0010)\end{array}$ & \\
Nordic/Anglo-Saxon countries & & 0.005 \\
Continental countries & & $(0.0074)$ \\
Mediterranean countries & & $(0.0072)$ \\
Transition countries & & $0.005^{*}$ \\
& & $(0.0031)$ \\
Number of observations & & 0.002 \\
Number of firms & 158,735 & 158,735 \\
Hansen test of overidentification $(p$ & 0.324 & 0.303 \\
value) & & \\
AR(2) ( $p$ value) & 0.110 & 0.212 \\
Number of instruments & 118 & 118 \\
\hline
\end{tabular}

Regressions are two-step system GMM estimator with firm-clustered and Windmeijer (2005)-corrected standard errors (in parentheses). All estimations include time dummies. All firm-level characteristics (except age) are treated as potentially endogenous variables. First differences of potential endogenous variables (dated $t-3$ and longer) are used as instruments in the level equation and level values of potential endogenous variables (dated $t-3$ and longer) are used as instruments in the differenced equation

Coefficients significant at ${ }^{*} 10 \% ;{ }^{*} 5 \% ;{ }^{* *} 1 \%$

labour costs. In contrast, for the group of countries with more labour market flexibility, the wage effects are significantly smaller or not significant. For example, in the Transition economies, the positive wage effects of a $10 \%$ points increase in foreign sales are associated with only a $1.2 \%$ increase in labour costs, whereas, in the Anglo Saxon and Nordic countries, the wage effects are not significant, suggesting that the higher levels of labour market flexibility enable the labour market to absorb the increased demand for skills. An interesting comparison is between the three richer groups. They have similar levels of absorptive capacity, illustrating the importance of labour market flexibility even when analysing markets for skilled labour in high-tech sectors. The above results provide clear support for the wage effects of inward investment: FDI consistently bids up the earnings of domestic workers in research-intensive sectors. Host country institutions also play a role, mitigating the combined effect of local labour demand and foreign technology. 
Table 6 Effect of FDI on domestic labour costs.

\begin{tabular}{|c|c|c|}
\hline $\begin{array}{l}\text { Dependent variable: log of unit labour } \\
\text { cost }\end{array}$ & [1] & {$[2]$} \\
\hline Unit labour cost $t-1$ & $\begin{array}{l}0.559^{* *} \\
(0.218)\end{array}$ & $\begin{array}{l}0.576^{\star \star} \\
(0.2582)\end{array}$ \\
\hline Employment $_{t-1}$ & $\begin{array}{l}-0.114 \\
(0.084)\end{array}$ & $\begin{array}{l}-0.189 \\
(0.129)\end{array}$ \\
\hline Size $_{t-1}$ & $\begin{array}{l}0.129 * \\
(0.07)\end{array}$ & $\begin{array}{l}0.118 \\
(0.1088)\end{array}$ \\
\hline Age $_{t-1}$ & $\begin{array}{l}-0.001 \\
(0.004)\end{array}$ & $\begin{array}{l}0.001 \\
(0.006)\end{array}$ \\
\hline Profitability $_{t-1}$ & $\begin{array}{l}0.004 \\
(0.004)\end{array}$ & $\begin{array}{l}0.003 \\
(0.008)\end{array}$ \\
\hline Cashflow $_{t-1}$ & $\begin{array}{l}0.001 \\
(0.002)\end{array}$ & $\begin{array}{l}0.001 \\
(0.003)\end{array}$ \\
\hline Market share $_{t-1}$ & $\begin{array}{l}-0.105^{\star} \\
(0.060)\end{array}$ & $\begin{array}{l}-0.039 \\
(0.105)\end{array}$ \\
\hline Capital $_{t-1}$ & $\begin{array}{l}0.001 \\
(0.018)\end{array}$ & $\begin{array}{l}-0.008 \\
(0.026)\end{array}$ \\
\hline Herfindahl index $x_{t-1}$ & $\begin{array}{l}0.000 \\
(0.0000)\end{array}$ & $\begin{array}{l}0.000 \\
(0.0000)\end{array}$ \\
\hline \multicolumn{3}{|l|}{$\begin{array}{l}\text { Foreign activity }_{t-1} \\
\quad \text { Within the region }\end{array}$} \\
\hline All countries & $\begin{array}{l}0.008^{* * *} \\
(0.0019)\end{array}$ & \\
\hline Nordic/Anglo-Saxon countries & & $\begin{array}{l}0.008 \\
(0.0050)\end{array}$ \\
\hline Continental countries & & $\begin{array}{l}0.024^{* * *} \\
(0.0085)\end{array}$ \\
\hline Mediterranean countries & & $\begin{array}{l}0.008^{* *} \\
(0.0037)\end{array}$ \\
\hline Transition countries & & $\begin{array}{l}0.0012^{\star *} \\
(0.0005)\end{array}$ \\
\hline \multicolumn{3}{|l|}{ Outside the region } \\
\hline All countries & $\begin{array}{l}-0.002 \\
(0.0016)\end{array}$ & \\
\hline Nordic/Anglo-Saxon countries & & $\begin{array}{l}-0.012 \\
(0.0160)\end{array}$ \\
\hline Continental countries & & $\begin{array}{l}0.004 \\
(0.0226)\end{array}$ \\
\hline Mediterranean countries & & $\begin{array}{l}0.000 \\
(0.0038)\end{array}$ \\
\hline Transition countries & & $\begin{array}{l}-0.005 \\
(0.0087)\end{array}$ \\
\hline \multicolumn{3}{|l|}{ Domestic activity $_{t-1}$} \\
\hline All countries & $\begin{array}{l}-0.001 \\
(0.0019)\end{array}$ & \\
\hline Nordic/Anglo-Saxon countries & & $\begin{array}{l}0.013 \\
(0.0208)\end{array}$ \\
\hline Continental countries & & $\begin{array}{l}-0.001 \\
(0.0088)\end{array}$ \\
\hline Mediterranean countries & & $\begin{array}{l}-0.001 \\
(0.0056)\end{array}$ \\
\hline Transition countries & & $\begin{array}{l}-0.004 \\
(0.0060)\end{array}$ \\
\hline Outside the region & & \\
\hline
\end{tabular}

Table 6 (Continued)

\begin{tabular}{lll}
\hline $\begin{array}{l}\text { Dependent variable: log of unit labour } \\
\text { cost }\end{array}$ & {$[1]$} & {$[2]$} \\
\hline All countries & 0.002 & \\
Nordic/Anglo-Saxon countries & $(0.0020)$ & \\
Continental countries & -0.016 \\
& & $(0.0359)$ \\
Mediterranean countries & -0.010 \\
Transition countries & & $(0.0175)$ \\
& & -0.000 \\
Number of observations & & $0.0052)$ \\
Number of firms & & 0.005 \\
Hansen test $(p$ value) & 151,567 & 151,567 \\
AR(2) ( $p$ value) & 39,753 & 39,753 \\
Number of instruments & 0.17 & 0.69 \\
\hline
\end{tabular}

Regressions are two-step system GMM estimator with firm-clustered and Windmeijer (2005)-corrected standard errors (in parentheses). All estimations include time dummies. All firm-level characteristics (except age) are treated as potentially endogenous. First differences of potential endogenous variables (dated $t-3$ and longer) are used as instruments in the level equation and level values of potential endogenous variables (dated $t-5$ and longer) are used as instruments in the differenced equation

Coefficients significant at * $10 \%$; $* * 5 \%$; $* * * 1 \%$

\section{Robustness Tests}

We carry out a robustness test by considering an alternative approach to our taxonomy. For the reasons explored above, we have employed a taxonomy based on the Sapir approach to labour market flexibility. However, there is the possibility that this fails to fully capture the distinction between regions within a country. As a robustness test, we, therefore, seek to capture the interaction between labour market flexibility and absorptive capacity in an alternative way, to allow for regional differences as well as national ones. We, therefore, replace the Sapir taxonomy with two alternative metrics. The first is an indicator of labour market flexibility per country, for which we use the OECD index of strictness of employment protection. The second is an indicator of absorptive capacity at the regional level (real GDP per capita in each region). The rational for the use of this measure is to capture the heterogeneity in potential spillovers across locations that has been identified in the literature. As mentioned in the conceptual framework section, Meyer and Sinani's (2009) meta-analysis of FDI spillovers shows that firms in higher income economies have higher capacity to absorb FDI 
spillovers. Thus, building on this, we further test our hypothesis here at a higher level of granularity by considering heterogeneity in potential spillovers across region, and not just simply across countries. To this end, we split our firms into 4 groups according to the level of labour market flexibility in the country in which they operate and their potential to absorb spillovers. We use the mean values of these indicators to classify our firms into each category.

- Group 1: High labour market flexibility and high GDP per capita

- Group 2: Low labour market flexibility and high GDP per capita

- Group 3: Low labour market flexibility and low GDP per capita

- Group 4: High labour market flexibility and low GDP per capita

The results from this alternative taxonomy are provided in appendix $\mathrm{B}$, and are in line with our main results in terms of our inferences regarding the importance of labour market flexibility and spillovers/absorptive capacity.

Finally, we estimated some long-run models, using the same approach but taking 'long differences' to explore any differences between short-run and long-run effects. The findings from these regressions do not differ from the results presented here, so are not reported.

\section{DISCUSSION AND CONCLUSIONS}

This paper explores the relationship between firm location and employment in research-intensive sectors. We show that simply extrapolating from previous models (developed to understand demand for unskilled workers in the West in the face of globalisation) is inadequate in a world where locations compete internationally for foreign investments and assets, and in which firms are engaged in a global war for talent.

We demonstrate that FDI into a location tends to increase demand for skilled labour in high-tech, research-intensive sectors. Specifically, the analysis presented above demonstrates that the presence of foreign firms has a positive effect on domestic wages in such labour markets, but that labour market flexibility and the capacity to absorb spillovers matter here. In line with our theoretical framework, we observe that inward investment significantly increases labour costs in the
Continental countries where higher levels of labour market inflexibilities and the potential of firms to absorb spillovers allow the domestic firms to increase earnings while retaining their workers. Similarly, the high levels of labour market inflexibility in the Mediterranean countries is also associated with an important increase in wages. However, due to the lower potential of domestic firms to absorb spillovers from FDI, those firms experience a loss in employment in the short run, in particular due to the pressure of FDI from outside their regions. In contrast, the effects of FDI on labour cost in countries with higher levels of labour market flexibility are smaller (i.e. in the Transition economies) or insignificant (i.e. in the Nordic and Anglo-Saxon countries), which in turn translates into less significant employment effects.

\section{Implications for Investment Promotion Agencies}

From the perspective of policy-makers, many locations are also involved in the competition to attract and retain not only high-tech firms but also highskill labour. If one starts, for example, by thinking of the relatively narrow concerns of most investment promotion agencies, they are under pressure to deliver new jobs and to protect existing ones. To a large extent, this is how they are evaluated, but this needs to be considered alongside the availability of skills locally, or the capacity for attracting in workers from elsewhere (either domestic or foreign) to meet demand. At the same time, however, with the increasing fragmentation of supply chains, locations need to understand their value proposition, not merely in terms of their offer to potential inward investors but also how the local conditions support the investment within the longer value chain. So, promotion agencies are focussed on a combination of employment creation, and potentially a trade-off between attracting the type of technology that suits available labour resources. In practice, what this often means is that many locations are chasing the same types of investment and seeking to develop comparative and competitive advantages in certain key sectors. One hears, for example, the same key phrases such as "advanced manufacturing", "digital and creative", "biotech" and "green technology" used in many inward investment strategies across the globe. By definition, this means a multitude of locations chasing a limited number of investments, often in sectors where labour markets are already tight, and skill shortages quickly become apparent. Equally, our findings also highlight the intense competition 
between domestic firms for the key resource of skilled labour. In locations with rigid labour markets, and significant skill shortages, inward investment acts merely to heighten this. This in turn places the emphasis on spillovers and absorptive capacity, in that the recipients of spillovers from inward investment will themselves crowd out other host country firms.

In addition, however, our results also highlight how a location's inward investment strategy needs to sit within its wider national or regional industrial strategy. For example, while we demonstrate that labour market flexibility is an important moderator of any adverse labour market effects of FDI, it is important to consider the drivers of labour market flexibility, especially in terms of skilled workers. Where hiring and retaining skilled workers is a key driver of a firm's location decisions, then inward investment strategy, in terms for example of focussing on certain sectors, cannot be divorced from education and training, or the support for small firms who provide ancillary services or inputs to high-tech firms, allowing such firms to employ their labour in the most efficient manner. At the same time, our results highlight the need for policies to promote innovation and encourage spillovers. R\&D and innovation policy can enhance domestic firms' absorptive capacity via incentivising $R \& D$ investment and innovation. These can raise firms' productivity, thus further strengthening domestic firms' ability to benefit from FDI. Moreover, at the same time, innovation-promoting policies, higher domestic R\&D and innovation, and greater productivity are all likely to increase the attractiveness of a region for foreign investors. The most prominent policy tools to increase R\&D and innovation are tax credits and direct subsidies. Furthermore, support of the university research system and of R\&D and innovation collaboration between universities and firms, i.e. the combination of education and innovation policies, have been shown to increase both the available pool of high-skilled labour and firm and industry R\&D and innovation. ${ }^{24}$

\section{Implications for the Multinational Firm}

These findings have implications for multinational enterprises. Our results suggest that the prevailing analysis of location decisions in terms of "availability of labour" needs to become more flexible, in order to understand the effects of these investments in terms of the multinationals' impact on local labour markets. As capital/labour ratios rise, the demand for, and returns to, skilled labour is ever increasing, and location decisions by multinational companies are being driven more by the need to service their demand for talent rather than the need to find cheap labour. The global 'war for talent' puts upward pressure on the earnings of that talent, and locations with concentrations of skilled workers will not be immune from these increasing wage costs. In turn, we argue that firms, when seeking, for example, investment support, tax incentives, support through regional or local initiatives, or other forms of public sector support for their investments, need to understand these processes as part of understanding their attractiveness to a region, in terms of jobs created and the impact on workers.

\section{Implications for Local Development Policy and Institutions}

To summarise, our results indicate that FDI improves the position of skilled workers and increases inequality rather than addressing unemployment. Given their higher productivity than the existing domestic firms, inward investors are able to attract workers through higher salaries that domestic firms are unable to match. Thus, FDI has the effect of moving research-intensive activity from domestic firms to inward investors in both the short and long runs, especially in locations with relatively inflexible labour markets and less potential to absorb spillovers.

This brings us to a wider understanding of the importance of local institutions, and of local and national policy. Our results highlight that the benefits to a region from FDI are lowest where there exists a combination of labour market inflexibility and low absorptive capacity. Taken together, these results suggest not simply a need to deregulate labour markets but also to consider a wider set of the drivers of labour market flexibility, as we discussed above. This suggests, for example, an emphasis on education and training. Skill shortages are forecast to become more acute in the future, especially in sectors related to high-end manufacturing and services. Inward investment in such locations will create employment in high-tech, research-intensive sectors, but skill provision needs to facilitate this. Higher levels of skills not only increases absorptive capacity but also helps labour markets' abilities to withstand shocks. At an individual level, the big winners from this process are the most skilled types of labour, and at a regional level it will be those locations that align their 
educational provision to the supply of the skills required by internationally mobile investors. Equally, however, higher levels of skills also increase labour mobility, which is also shown to boost spillovers from inward investment.

Our findings illustrate the importance of policy and institutions in explaining the link between motives for FDI and its effects. The importance of national (labour market) analysis reflects both the strategic location decisions of MNEs, and the need for locations to stimulate employment or attract new technology. The interactions between internationalisation, labour market flexibility and skill shortages highlight the need for research to recognise these interwoven considerations and definitions of place.

Finally, this places the emphasis on policy-makers to better understand the drivers of spillovers from inward investment. The academic literature has focussed on quantifying these, with debates typically centring around the distinction between horizontal and vertical effects or the motivation of FDI, in addition to absorptive capacity. Our analysis highlights the need for policy-makers to understand the importance of place, not just in terms of local effects, through co-location or clustering, as the academic literature highlights, but also interregional effects, both in terms of technological spillovers, but also labour market spillovers. This places the onus on policy-makers to understand not only the precise nature of spillover mechanisms but also the nature of local and regional labour markets. There needs to be a focus on the interaction between labour markets, skills and the drivers of productivity at a local level, in order to fully understand how to maximise the benefits of attracting internationally mobile capital. While there exists a wide range of academic studies in this area, this places onus on both academics and policy-makers to bridge this gap. An immediate issue for policy-makers, therefore, is how they interpret these academic studies, within their local setting, acknowledging the juxtaposition concerning skilled and unskilled employment effects, direct technology transfer between parent and affiliate, and finally the indirect effects (spillovers) and potential competition with local firms. Our role, as academics with an interest in policy, is to provide an understanding of the types of firms who may invest in the region, and, perhaps more importantly, who may do so in the future, in terms of maximising the gains from a very limited set of resources to attract investment.

\section{LIMITATIONS}

We must acknowledge the limitations of our analysis. As with all firm-level econometric analysis, we infer the mechanisms by which businesses react to the pressures of competing in research-intensive labour markets from the estimates obtained over a large sample. Of course, firms may react to similar circumstances in many different ways. Therefore, to better understand the precise processes by which firms react to such situations, detailed analysis of individual businesses is required. This could be both longitudinal, to see how specific businesses change strategies through time, and comparative analysis which can provide insights on how otherwise similar businesses in different institutional settings react to FDI in research-intensive labour markets. Both forms of analysis would be complementary to the statistical analysis described above.

Our analysis indicates that labour market flexibility plays a key role in moderating the wage and employment effects of FDI in research-intensive labour markets. Our categorisation of labour market flexibility is based on Sapir (2005). This is both an intuitive taxonomy and one which has a track record in European labour market studies, and clearly provides some traction in the empirical analysis. It closely follows the 'varieties of capitalism' approach familiar in IB. We acknowledge, however, that this is only one possible means of categorising labour market flexibility, and that ultimately there may be substantial differences within the (national) labour market institutions that make up each of the four groupings. Further exploration of these national institutional differences would add granularity to the role of labour market institutions in moderating the effects of FDI. More generally, our findings suggest that labour market analysis should form a greater element of the consideration of firms' location decisions. Hitherto, much of this analysis takes a very broad brush approach to including labour market analysis in location modelling, such as simply availability of labour through (un)employment patterns or average labour cost in the region. Our analysis suggests that such approaches are inadequate, especially in sectors characterised by high technology and skilled labour. At the same 
time, locations need to understand their value proposition to firms, especially where labour is tight. From both perspectives, this highlights the need for more detailed modelling of the availability of (skilled) labour when modelling location decisions or a region's ability to attract inward investment.

Finally, while our general results on the moderating role of labour market flexibility and spillovers continue to stand, our results for the specific countries considered may need to be updated if labour market policies were to significantly alter the degree of labour market flexibility in any country, or technology policy was to alter the degree of productivity spillovers.

\section{NOTES}

${ }^{1}$ It has been documented that such researchdriven high-skill sectors have seen wage inflation well above average over the past 10 years. For example, the Bureau of Labor Statistics reported an average $27 \%$ year on year increase in wage rates in high-tech sectors for the US from 2001 to 2009. (http://www.bls.gov/opub/ted/2011/ted_20111207. $\mathrm{htm})$. Equally, in a survey of Indian Business, the Mercer Group (2013) projected salary increases of above $10 \%$ for Indian skilled workers for 2016, with high-tech sectors significantly above this (http:// www.hrkatha.com/news/555-mercer-predicts-anaverage-salary-increase-of-10-5-per-cent-in-2016). In a similar study for Asia, similar effects are reported https://www.towerswatson.com/en/Press/2015/10/ Rising-Inflation-Set-to-Trim-2016-Salary-Raises-inAsia-Pacific

${ }^{2}$ See, e.g., Javorcik and Spatareanou (2005), Gross and Ryan (2008), Dewit, Görg, H., \& Montagna (2009), Leibrecht and Scharler (2009) and Busse, Nunnenkamp, and Spatareanu (2011).

${ }^{3}$ For a review, see Görg and Strobl (2001).

${ }^{4}$ Recent microeconometric literature on the employment effects of innovation, which as we discuss above is the basis for competition in research-intensive, high-tech, sectors and a factor in the location decision by MNEs, as well as one indicator of absorptive capacity, finds that innovation has an employment-creating effect generally only in high-tech sectors, which are characterised by higher $R \& D$ intensity and the prevalence of product, in comparison to process, innovation. These studies have predominantly been carried out using European or US data. They are summarised in Van Roy et al (2018), whose own analysis on technical and patentable innovation activity by firms in 22 European countries concurs with these results.

${ }^{5}$ In their analysis of FDI inflows in high-skill versus low-skill activities on job polarisation in 26 European countries, Amoroso and MoncadaPaternò-Castello (2018) call for the consideration of institutional frameworks, which may impact labour markets' responsiveness to technological change, as well as for the exploration of regional heterogeneities.

${ }^{6}$.For applications of the Sapir (2006) approach, see for example: Fassin et al. (2015), Maon, Swaen, and Lindgreen (2017), Mussida and Fabrizi (2014), Kahn-Nisser (2015), Nunez and Livanos (2015), Ward-Warmedinger and Macchiarelli (2014) and Kretsos and Livanos (2016).

${ }^{7}$ We do this partly for the practical reason that, in the data described below, the domestic sector in the Anglo-Saxon group is relatively small, leading to relatively few observations in this group. However, our results remain robust when we consider five groups of countries instead of four (available on request). We also explore an alternative approach to capturing labour market flexibility and discuss this robustness test below.

${ }^{8}$ In order to illustrate the variation in labour market flexibility across these groups of countries, Fig. A1 in appendix A shows an OECD indicator of labour market flexibility (i.e. the index of protection of permanent workers against individual and collective dismissals). As Figure A1 shows, the Continental and Mediterranean countries lie on the right-hand side, indicating lower levels of labour market flexibility than Transition and Nordic and Anglo-Saxon countries. It is worth noting, however, that the distribution of the values within the group of Nordic and Anglo-Saxon countries is in general more dispersed than in any other group, which reflects the fact that the level of labour protection is significantly lower in the United Kingdom $(\mathrm{EPRC}=1.6)$ compared with, for example, the Netherlands $(\mathrm{EPRC}=2.9)$. Of the Transition countries, the most flexible are on a par with the most flexible Anglo-Saxon countries, while even the least flexible transition countries are more flexible than continental Europe. This is discussed in detail in Drahokoupil, Myant, and Domonkos (2015) and Lehmann and Muravyev (2012). 
${ }^{9}$ With data such as these, there is a concern regarding coverage and representation. Here, we follow the analysis of Ribeiro et al (2010), who map the ORBIS data onto official OECD sector level data to test the representative data of ORBIS. They find no such problems.

${ }^{10}$ The main limitation of ORBIS is its structural bias as it covers only firms with balance-sheet information, leaving the smallest enterprises underrepresented. This limitation is, however, common to any other administrative databases and most official databases produced by national statistical offices.

${ }^{11}$ We track foreign firms in ORBIS as those companies with foreign shareholder(s) (i.e. shareholders located in a different countries) who are the ultimate owner(s) of the company, with a direct participation greater than $51 \%$.

${ }^{12}$ Eurostat aggregates the manufacturing industries according to the level of their technological intensity, measured as $\mathrm{R} \& \mathrm{D}$ expenditure as a ratio of value added. The four classifications used by Eurostat for manufacturing industries are 'hightechnology', 'medium-high-technology', 'mediumlow-technology' and 'low-technology', whilst services industries are mainly grouped together into 'knowledge-intensive services' and 'less knowledge intensive services' (see http://ec.europa.eu/ eurostat/statistics-explained/index.php/Glossary:

High-tech). We use both manufacturing industries in the first category (21 and 26) and two from the second category (20 and 27) (see http://ec.europa. eu/eurostat/statistics-explained/index.php/

Glossary:High-tech_classification_of_ manufacturing_industries), plus the two knowledge-intensive services sectors 72 and 74 .

${ }^{13}$ In this paper, the region $r$ refers to administrative divisions within a country (i.e. states, provinces, autonomous communities, federal states, counties, municipalities, etc.). The industry $j$ refers to the 4-digit industry level within each 2-digit classification.

${ }^{14}$ The precise definition of the variables used in our analysis is provided in Table A2 in Appendix A.

${ }^{15}$ Such unobserved time-invariant factors include firm-specific effects (i.e. firm's human capital endowments, working conditions, managerial ability, etc.) as well as regional- and industry-specific effects.

${ }^{16}$ The reason that we use sales rather than employment as our measure of inward investment penetration is to avoid the double-counting or spurious correlation that may arise, for example, if employment changes in foreign and domestic firms are linked due to structural labour market adjustments at the country or sectoral level.

${ }^{17}$ The coefficients $\sum_{g=1}^{4} \beta_{3 g}$ provide the direct effect of foreign activity within a region on domestic employment in each group of countries $\left(D_{g} ; g=1, \ldots 4\right)$. For example, the coefficient $\beta_{32}$ in Eq. (1) is the average effect of increasing local within-region - foreign activity on domestic employment in group $2(g=2)$ Note that this approach is equivalent to selecting a base group (for example $g=1$ ) and comparing the corresponding estimated coefficients on the interaction term against the base group. For example, the coefficient $\beta_{42}$ is the average effect of increasing national outside-region but within-country - foreign activity on domestic employment in group 2 compared to group 1.

${ }^{18}$ Hence, our model specification captures, for instance, Marek and Gauselmann's (2012) finding that foreign activity agglomerates in a number of sub-national regions. Since we are investigating high-tech, R\&D/innovation-intensive sectors, in whichever region within a country these are located, our model also takes account of the results of Basile, Castellani, and Zanfei (2008) and Jindra, Hassan, and Cantner (2016) that, if a region in the EU27 becomes less attractive, due to a change in some of its observable or unobservable attributes, foreign firms seem more likely to choose other regions sharing a similar industrial structure, for example, and this applies even more so in the case of the spatial distribution and concentration of $R \& D$ (and foreign $R \& D$ ). For a proposition of a hierarchy of sub-national regions, see Cantwell and Iammarino (2001).

${ }^{19}$ See also Dickens and Katz (1987).

${ }^{20}$ The set of observed firms' characteristics including sales, profitability, cashflow, capital, and market share as well as the employment and labour cost variables are suspected to be endogenous, whereas firms' age, the external (to the firm) variables and a set of time, country, and industry dummies are regarded as exogenous variables.

${ }^{21}$ Specific details about the choices adopted in the GMM estimations are reported at the bottom of the results tables. Also, as suggested by Roodman (2009), we carried out a number of checks including reducing the instrument count and using orthogonal deviations instead of first differences. The main results remain robust to these changes. 


\author{
${ }^{22}$ Note that our estimation is performed at the 4- \\ digit industry level within each 2-digit \\ classification. \\ ${ }^{23}$ As a robustness test, we also split the Anglo- \\ Saxon/Nordic countries into two groups and find \\ similar results.
}

${ }^{24}$ More details on these effects of $R \& D$ and innovation policies can be found in the recent literature reviews by Dimos and Pugh (2016), Becker (2015) and Zuniga-Vicente, Alonso-Borrego, Forcadell, and Galan (2014).

\section{REFERENCES}

Acemoglu, D. 2002. Technical change, inequality and the labor market. Journal of Economic Literature, XL: 7-72.

Acemoglu, D., \& Autor, D. 2011. Skills, tasks and technologies: Implications for employment and earnings. In O. Ashenfelter \& D. Card (Eds.), Handbook of labor economics, vol. 4, Part $B$ (pp. 1043-1171). Amsterdam: Elsevier.

Aitken, B., Harrison, A., \& Lipsey, R. E. 1996. Wages and foreign ownership. A comparative study of Mexico, Venezuela and the United States. Journal of International Ecconomics, 40: 345371.

Amoroso, S., \& Moncada-Paternò-Castello, P. 2018. Inward greenfield FDI and patterns of job polarization. Sustainability, 10: 1219-1238.

Barrell, R., \& Pain, N. 1997. Foreign direct investment, technological change and economic growth within Europe. Economic Journal, 107: 1770-86.

Basile, R., Castellani, D., \& Zanfei, A. 2008. Location choices of multinational firms in Europe: The role of EU cohesion policy. Journal of International Economics, 74: 328-340.

Becker, B. 2015. Public R\&D policies and private R\&D investment: A survey of the empirical evidence. Journal of Economic Surveys, 29(5): 917-942.

Beechler, S., \& Woodward, I. 2009. The global "war for talent". Journal of International Management, 15(3): 273-285.

Benfratello, L., \& Sembenelli, A. 2006. Foreign ownership and productivity: Is the direction of causality so obvious? International Journal of Industrial Organization, 24(4): 733-751.

Blundell, R., \& Bond, S. 1998. Initial conditions and moment restrictions in dynamic panel data models. Journal of Econometrics, 87: 115-43.

Busse, M., Nunnenkamp, P., \& Spatareanu, M. 2011. Foreign direct investment and labour rights: A panel analysis of bilateral FDI flows. Applied Economics Letters, 18: 149-152.

Butcher, K., \& Card, D. 1991. Immigration and wages: Evidence from the 1980s. American Economic Review, 81(May): 262266.

Cantwell J. A. M., \& lammarino, S. 2001. EU regions and multinational corporations: Change, stability and strengthening of technological comparative advantages. Industrial and Corporate Change, 10(4): 1007-1037.

Cantwell, J., \& Smeets, R. 2013. FDI motives and host country productivity effects of US MNEs. In F. De Beule, \& Y. Nauwelaerts (Eds.), Innovation and creativity: Pillars of the future global economy (pp. 173-196). Cheltenham: Edward Elgar.

Cao, J., \& Mukherjee, A. 2013. Foreign direct investment. Mimeo: Unionised Labour Markets and Welfare.

Card, D. 1990. Unexpected inflation, real wages, and employment determination in union contracts. American Economic Review, 18: 669-688.

Caves, R. E. 1996. Multinational enterprise and economic analysis. Cambridge: Cambridge University Press.

Chambers, E., Foulon, M., Handfield-Jones, H., Hankin, S., Michaels III, E. 1998. The war for talent. The McKinsey Quarterly, 3: 44-57.

Clougherty, J. A., Gugler, K., Sørgard, L., \& Szücs, F. W. 2014. Cross-border mergers and domestic-firm wages: Integrating "spillover effects" and "bargaining effects". Journal of International Business Studies, 45(4): 450-470.

Crescenzi, R., Gagliardi, L., \& lammarino, S. 2015. Foreign multinationals and domestic innovation: Intra-industry effects and firm heterogeneity. Research Policy, 44(3): 596-609.

Crescenzi R., Pietrobelli C., \& Rabellotti R. 2014. Innovation drivers, value chains and the geography of multinational corporations in Europe. Journal of Economic Geography, 14(6): 1053-1086.

Crespo, N., Fontoura, M. P., \& Proenca, I. 2009. FDI spillovers at regional level: Evidence from Portugal. Papers in Regional Science, 88(3): 591-607.

Cuñat, A., \& Melitz, M. J. 2012. Volatility, labor market flexibility, and the pattern of comparative advantage. Journal of the European Economic Association, 10: 225-254.

Dewit, G., Görg, H., \& Montagna, C. 2009. Should I stay or should I go? Foreign direct investment, employment protection and domestic anchorage. Review of World Economics, 145: 93-110.

Dickens, W. T., \& Katz, L. F. 1987. Inter-industry wage differencesand industry characteristics. In K. Lang, \& J. S. Leonard (Eds.), Unemployment and the structure of labor markets (pp. 48-89). New York: Basil Blackwell.

Dimos, C., \& Pugh, G. 2016. The effectiveness of R\&D subsidies: A meta-regression analysis of the evaluation literature. Research Policy, 45(4): 797-815.

Drahokoupil, J., Myant, M.,, \& Domonkos, S. 2015. The politics of flexibility: Employment practices in automotive multinationals in Central and Eastern Europe. European Journal of Industrial Relations, 21(3): 223-240.

Drahokoupil, J., \& Myant, M. 2015. Putting comparative capitalisms research in its place: Varieties of capitalism in transition economies. In New directions in comparative capitalisms research (pp. 155-171). London: Palgrave Macmillan.

Driffield, N. L. 1999. Indirect employment effects of foreign direct investment into the UK. Bulletin of Economic Research, 51: 207-221.

Driffield, N. L. (2001). The impact on domestic productivity of inward investment in the UK. The Manchester School, 69(1): 103-119.

Driffield, N. 2006. On the search for spillovers from foreign direct investment (FDI) with spatial dependency. Regional Studies, 40(1): 107-119.

Driffield, N. \& Girma, S. 2003. Regional foreign direct investment and wage spillovers: Plant level evidence from the U.K Electronics Industry. Oxford Bulletin of Economics and Statistics, 65(4): 453-474.

Driffield, N., \& Love, J. H. 2007. Linking FDI motivation and host economy productivity effects: Conceptual and empirical analysis, Journal of International Business Studies, 38(2): 460473.

Driffield, N., Love, J. H., \& Taylor, K.. 2009. Productivity and labour demand effects of inward and outward FDI on UK industry. Manchester School, 77(2): 171-203.

Driffield, N., Love, J. H., \& Taylor, K. 2010. The multinational enterprise as a source of international knowledge flows: Direct evidence from Italy. Journal of International Business Studies, 41(2): $350-359$. 
Driffield, N. L., \& Taylor, K. 2000. FDI and the labour market: A review of the evidence and policy implications. Oxford Review of Economic Policy, 16(3): 90-103.

Driffield, N., \& Taylor, K. 2006. Wage spillovers, inter-regional effects and the impact of inward investment. Spatial Economic Analysis, 1(2): 187-205.

Dunning, J. H. 1979. Explaining patterns of international production: In defence of the Eclectic theory. Oxford Bulletin of Economics and Statistics, 41: 269-95.

Fassin, Y., Werner, A., Van Rossem, A., Signori, S., Garriga, E., von Weltzien Hoivik, H., \& Schlierer, H. J. 2015. CSR and related terms in SME owner-managers' mental models in six European countries: National context matters. Journal of Business Ethics, 128(2): 433-456.

Girma, S. 2005. Absorptive capacity and productivity spillovers from FDI: A threshold regression analysis. Oxford Bulletin of Economics and Statistics, 67(3): 281-306.

Girma, S., Greenaway, D., \& Wakelin, K. 2001. Who benefits from foreign direct investment in the UK? Scottish Journal of Political Economy, 48: 119-133.

Girma, S., Görg, H., \& Kersting, E. 2019. Which boats are lifted by a foreign tide? Direct and indirect wage effects of foreign ownership. Journal of International Business Studies, 50(6): 923-947.

Gross, D. M. \& Ryan, M. 2008. FDI location and size: Does employment protection legislation matter? Regional Science and Urban Economics, 38: 590-605.

Görg, H., \& Greenaway, D. 2004. Much ado about nothing? Do domestic firms really benefit from foreign direct investment? The World Bank Research Observer, 19(2): 171-197.

Görg, H., \& Strobl, E. 2001. Multinational companies and productivity spillovers: A meta-analysis. Economic Journal, 111(475): 723-739.

Hall, P. A., \& Soskice, D. (2001). Varieties of Capitalism: The Institutional Foundations of Comparative Advantage. Oxford: Oxford University Press.

Hijzen, A., Görg, H., \& Hine, R. C. 2005. International outsourcing and the skill structure of labour demand in the United Kingdom. Economic Journal, 115: 860-878.

Javorcik, B. S., \& Spatareanu, M. 2005. Do foreign investors care about labor market regulations? Journal of Review of World Economics, 141(3): 375-403.

Jindra, B., Hassan, S. S. \& Cantner, U. 2016. What does location choice reveal about knowledge-seeking strategies of emerging market multinationals in the EU? International Business Review, 25: 204-220.

Kafouros M. I., Buckley, P. J., \& Clegg, J. 2012. The effects of global knowledge reservoirs on the productivity of multinational enterprises: The role of international depth and breadth, Research Policy, 41(5): 848-861.

Kahn-Nisser, S. 2015. The hard impact of soft co-ordination: Emulation, learning, and the convergence of collective labour standards in the EU. Journal of European Public Policy, 22(10): 1512-1530.

Katz, L., \& Autor, D. 1999. Changes in the wage structure and earnings inequality. In O. Ashenfelter and D. Card (Eds.), Handbook of labor economics: Vol 3A. Amsterdam: Elsevier.

Kretsos, L., \& Livanos, I. 2016. The extent and determinants of precarious employment in Europe. International Journal of Manpower, 37(1): 25-43.

Lehmann, H., \& Muravyev, A. 2012. Labour market institutions and labour market performance: What can we learn from transition countries? Economics of Transition, 20(2): 235-269.

Leibrecht, M. \& Scharler, J. 2009. How important is employment protection legislation for foreign direct investment flows in central and Eastern European countries? Economics of Transition, 17: 275-295.

Machin, S. 2003. The changing nature of labor demand in the new economy and skill-biased technology change. Oxford Bulletin of Economics \& Statistics, 63(S1): 753-776.
Maon, F., Swaen, V., \& Lindgreen, A. 2017. One vision, different paths: An investigation of corporate social responsibility initiatives in Europe. Journal of Business Ethics, 143(2): 405422.

Marek, P. \& Gauselmann, A. 2012. Regional determinants of MNEs location choice in post-transition. Empirica, 39(4): 487511.

Markusen, J. R., \& Venables, A. J. 1999. Foreign direct investment as a catalyst for industrial development. European Economic Review, 43(2): 335-356.

Meyer, K. E., \& Sinani, E. 2009. When and where does foreign direct investment generate positive spillovers? A meta-analysis. Journal of International Business Studies, 40(7): 1075-1094.

Monastiriotis, V. 2005. Labour market flexibility in the UK: Regional variations and the role of global/local forces. Economic and Industrial Democracy, 26(3): 443-477.

Mussida, C., \& Fabrizi, E. 2014. Unemployment outflows: The relevance of gender and marital status in Italy and Spain. International Journal of Manpower, 35(5): 594-612.

Narula, R. 2019. Enforcing higher labor standards within developing country value chains: Consequences for MNEs and informal actors in a dual economy. Journal of International Business Studies, 50(9): 1622-1635.

Nunez, I., \& Livanos, I. 2015. Temps "by choice"? An investigation of the reasons behind temporary employment among young workers in Europe. Journal of Labor Research, 36(1): 4466.

Nölke, A., \& Vliegenthart, A. 2009. Enlarging the varieties of capitalism: The emergence of dependent market economies in East Central Europe. World Politics, 61(4): 670-702.

Ribeiro, S. P., Menghinello, S., \& Backer, K. D. 2010. The OECD ORBIS database: Responding to the need for firm-level microdata in the OECD. OECD Statistics Working Papers 2010/1.

Rodrik, D. 1999. The new global economy and developing countries: Making openness work. Policy Essay No. 24. In Overseas Development Council. Baltimore, MD: Johns Hopkins University Press.

Rojec, M., \& Mark, K. 2018. Why is there a lack of evidence on knowledge spillovers from foreign direct investment? Journal of Economic Surveys, 32(3): 579-612.

Roodman, D. M. 2009. How to do xtabond2: An introduction to difference and system GMM in Stata. The Stata Journal, 9: 86136.

Van Roy, V., Vértesy, D. \& Vivarelli, M. 2018. Technology and employment: Mass unemployment or job creation? Empirical evidence from European patenting firms. Research Policy, 47(9): 1762-1776.

Sapir, A. 2005. Globalisation and the Reformof European Social Models Background document for the presentation at ECOFIN Informal Meeting in Manchester, 9 September 2005. www. brugel.org.

Sapir, A. 2006. Globalization and the reform of European social models. Journal of Common Market Studies, 44(2): 369-390.

Sapir, A. 2014. Still the right agenda for Europe? The Sapir Report ten years on. Journal of Common Market Studies, 52(S1): 57-73.

Smeets, R. 2008. Collecting the pieces of the FDI knowledge spillovers puzzle. World Bank Research Observer, 23(2): 107138.

Soltwedel, R., Dohse, D. \& Kreiger-Boden, C. 1999. EMU challenges and European Labour Markets. IMF Working Paper $99 / 131$

Van der Straaten, K., Pisani, N. \& Kolk, A. 2019. Unravelling the MNE wage premium. Journal of International Business Studies. https://doi.org/10.1057/s41267-019-00285-x

Taylor, K. \& Driffield, N. L. 2005. Wage dispersion and the role of multinationals: Evidence from UK panel data. Labour Economics, 12: 223-249.

Teixeira, A. A., \& Tavares-Lehmann, A. T. 2014. Human capital intensity in technology-based firms located in Portugal: Does foreign ownership matter? Research Policy, 43(4): 737-748. 
Temouri, Y., Driffield, N. L. \& Higon, D. A. 2008. Analysis of productivity differences among foreign and domestic firms: Evidence from Germany. The Review of World Economics, 144(1): 32-54.

UNCTAD. 2013. World Investment Report: Global value chains: Investment and trade for development. Geneva: UNCTAD.

Ward-Warmedinger, M., \& Macchiarelli, C. 2014. Transitions in labour market status in EU labour markets. IZA Journal of European Labor Studies, 3(1): 17.

Windmeijer, F. 2005. A finite sample correction for the variance of linear efficient two-step GMM estimators. Journal of Econometrics, 126(1): 25-51.
Witt, M. A \& Jackson, G. 2016. Varieties of Capitalism and institutional comparative advantage: A test and reinterpretation. Journal of International Business Studies, 47(7): 778-806.

Zuniga-Vicente, J. A., Alonso-Borrego, C., Forcadell, F. J., Galan, J. I. 2014. Assessing the effect of public subsidies on firm R\&D investment: A survey. Journal of Economic Surveys, 28(1): 3667.

See Tables A1, A2, Fig. A1.

\section{APPENDIX A: ANALYSIS BASED ON SAPIR TAXONOMY}

Table A1 Categories of countries according to their labour market institutions.

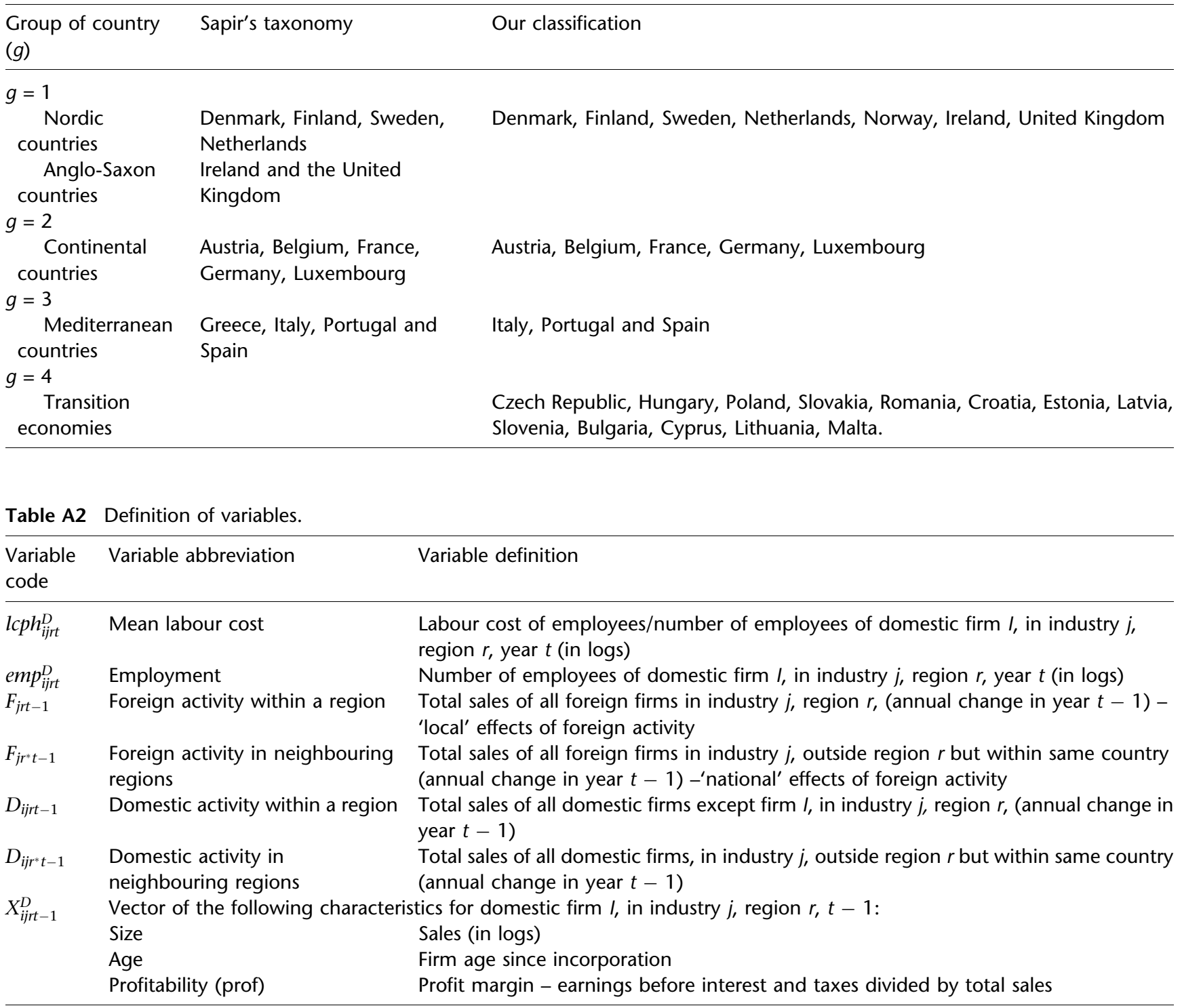


Table A2 (Continued)

\begin{tabular}{|c|c|c|}
\hline $\begin{array}{l}\text { Variable } \\
\text { code }\end{array}$ & Variable abbreviation & Variable definition \\
\hline & Cash flow (cash) & Cash flow/total assets \\
\hline & Market share (mksh) & Sales of firm $1 /$ total sales of all firms in firm's industry in region $r$ \\
\hline & Capital (cap) & Fixed assets (in logs) \\
\hline$H_{\text {jrt-1 }}$ & Herfindahl index & $\begin{array}{l}\text { Sum of the squares of the market shares of the } 50 \text { largest firms in industry } j \text {, region } r \\
\text { (or summed over all firms in industry } j \text { when there are fewer than } 50 \text { firms in industry } j \text { ) }\end{array}$ \\
\hline$D_{g}$ & Indicator variables for each group & of countries classified according to their labour market institutions as defined in Table A1 \\
\hline$D_{1}$ & $\begin{array}{l}\text { Nordic/Anglo-Saxon countries } \\
\text { dummy variable }\end{array}$ & $=1$ if firm is located in any of the Nordic or Anglo/Saxon countries, 0 otherwise \\
\hline$D_{2}$ & $\begin{array}{l}\text { Continental countries dummy } \\
\text { variable }\end{array}$ & $=1$ if firm is located in any of the Continental countries, 0 otherwise \\
\hline$D_{3}$ & $\begin{array}{l}\text { Mediterranean countries dummy } \\
\text { variable }\end{array}$ & $=1$ if firm is located in any of the Mediterranean countries, 0 otherwise \\
\hline$D_{4}$ & $\begin{array}{l}\text { Transition economies dummy } \\
\text { variable }\end{array}$ & $=1$ if firm is located in any of the Transition economies, 0 otherwise \\
\hline
\end{tabular}

Note All monetary variables are expressed in real terms.

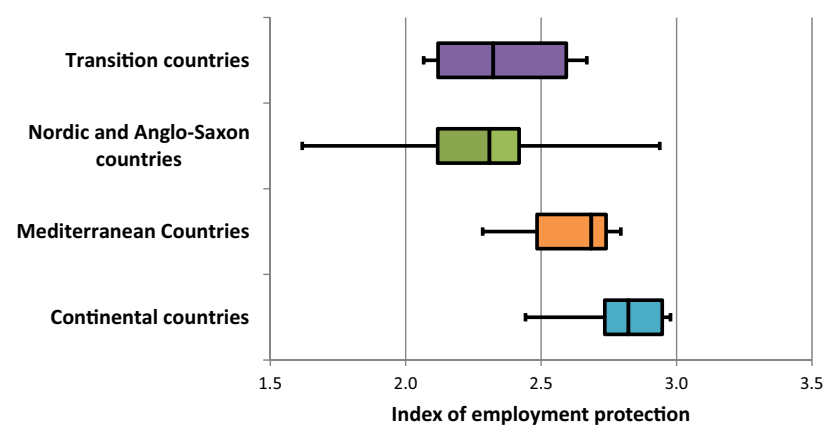

\footnotetext{
Notes: the Index of employment protection indicates the level of protection of permanent workers against individual and collective dismissals. Scale from 0 (least restrictions) to 6 (most restrictions). See OECD (2013, Chapter 2) for details on the methodology used to calculate this index.

In the above graph the employment protection index is sorted for each group of countries and four equal groups are made from these ordered indexes. The extreme values of the whiskers in each diagram represent the upper and lower values of the index; the middle line within the box indicates the median value; and the ends of the box represent the lower and upper quartile values.
}

Transition countries include: Czech Rep., Estonia, Hungary, Latvia, Poland, Slovak Rep., and Slovenia

Source: OECD Indicators of Employment Protection, available at:

http://www.oecd.org/employment/emp/oecdindicatorsofemploymentprotection.htm.

Fig. A1 Employment Protection of permanent workers by groups of countries: 2013. 


\section{APPENDIX B: ROBUSTNESS TEST}

See Tables B1, B2.

Table B1 Effect of FDI on domestic employment.

\begin{tabular}{|c|c|}
\hline Dependent variable: log of employment & {$[1]$} \\
\hline Employment $t-1$ & $\begin{array}{l}0.985^{* * *} \\
(0.1517)\end{array}$ \\
\hline Unit labour cost $t-1$ & $\begin{array}{l}0.048 \\
(0.1638)\end{array}$ \\
\hline Size $_{t-1}$ & $\begin{array}{l}0.065 \\
(0.1082)\end{array}$ \\
\hline $\operatorname{Age}_{t-1}$ & $\begin{array}{l}-0.005 \\
(0.0049)\end{array}$ \\
\hline Profitability $_{t-1}$ & $\begin{array}{l}0.008^{* *} \\
(0.0038)\end{array}$ \\
\hline Cashflow $_{t-1}$ & $\begin{array}{l}-0.002 \\
(0.0018)\end{array}$ \\
\hline Market share $_{t-1}$ & $\begin{array}{l}-0.134 \\
(0.0957)\end{array}$ \\
\hline Capital $_{t-1}$ & $\begin{array}{l}-0.020 \\
(0.0233)\end{array}$ \\
\hline Herfindahl $_{t-1}$ & $\begin{array}{l}-0.000 \\
(0.0000)\end{array}$ \\
\hline \multicolumn{2}{|l|}{ Foreign activity $t-1$} \\
\hline Group 1 & $\begin{array}{l}0.010 \\
(0.0095)\end{array}$ \\
\hline Group 2 & $\begin{array}{l}0.002 \\
(0.0021)\end{array}$ \\
\hline Group 3 & $\begin{array}{l}0.002 \\
(0.0020)\end{array}$ \\
\hline Group 4 & $\begin{array}{l}0.000 \\
(0.0031)\end{array}$ \\
\hline \multicolumn{2}{|l|}{ Outside the region } \\
\hline Group 1 & $\begin{array}{l}0.009 \\
(0.0097)\end{array}$ \\
\hline Group 2 & $\begin{array}{l}0.000 \\
(0.0041)\end{array}$ \\
\hline Group 3 & $\begin{array}{l}-0.005^{*} \\
(0.0027)\end{array}$ \\
\hline Group 4 & $\begin{array}{l}-0.001 \\
(0.002)\end{array}$ \\
\hline \multicolumn{2}{|l|}{ Domestic activity $_{t-1}$} \\
\hline Group 1 & $\begin{array}{l}(0.0045) \\
0.008\end{array}$ \\
\hline Group 2 & $\begin{array}{l}(0.0133) \\
-0.000\end{array}$ \\
\hline Group 3 & $\begin{array}{l}(0.0043) \\
0.002\end{array}$ \\
\hline Group 4 & $\begin{array}{c}(0.0029) \\
-0.003 \\
(0.0034)\end{array}$ \\
\hline Outside the region & \\
\hline Group 1 & 0.005 \\
\hline
\end{tabular}

Table B1 (Continued)

Dependent variable: log of employment

[1]

Group 2

$(0.0207)$

0.002

Group 3

$(0.0061)$

$-0.001$

Group 4

$(0.0049)$

0.003

(0.0062)

Number of observations

155250

Number of firms

40575

Hansen test ( $p$ value) $\quad 0.444$

$\operatorname{AR}(2)$ ( $p$ value) $\quad 0.665$

Number of instruments

Regressions are two-step system GMM estimator with firm-clustered and Windmeijer (2005)-corrected standard errors (in parentheses). All estimations include time dummies. All firm-level characteristics (except age) are treated as potentially endogenous. First differences of potential endogenous variables (dated $t-4$ and longer) are used as instruments in the level equation and level values of potential endogenous variables (dated $t-4$ and longer) are used as instruments in the differenced equation

Coefficients significant at ${ }^{*} 10 \% ;{ }^{* *} 5 \% ;{ }^{* * *} 1 \%$

Table B2 Effect of FDI on domestic labour costs.

\begin{tabular}{|c|c|}
\hline Dependent variable: log of labour cost & {$[1]$} \\
\hline Labour cost $_{t-1}$ & $\begin{array}{l}0.418^{* *} \\
(0.2)\end{array}$ \\
\hline Employment $_{t-1}$ & $\begin{array}{l}0.118 \\
(0.2334)\end{array}$ \\
\hline Size $_{t-1}$ & $\begin{array}{l}0.219 * \\
(0.1234)\end{array}$ \\
\hline Age $_{t-1}$ & $\begin{array}{l}0.001 \\
(0.0099)\end{array}$ \\
\hline Profitability $_{t-1}$ & $\begin{array}{l}-0.001 \\
(0.0073)\end{array}$ \\
\hline Cashflow $_{t-1}$ & $\begin{array}{l}0.001 \\
(0.0028)\end{array}$ \\
\hline Market share ${ }_{t-1}$ & $\begin{array}{l}-0.192^{* *} \\
(0.0547)\end{array}$ \\
\hline Capital $_{t-1}$ & $\begin{array}{l}-0.011 \\
(0.0358)\end{array}$ \\
\hline Herfindahl index $x_{t} 1$ & $\begin{array}{l}0.000 \\
(0.0000)\end{array}$ \\
\hline \multicolumn{2}{|l|}{$\begin{array}{l}\text { Foreign activity } t-1 \\
\text { Within the region }\end{array}$} \\
\hline Group 1 & $\begin{array}{l}-0.021 \\
(0.0264)\end{array}$ \\
\hline Group 2 & $\begin{array}{l}0.0093^{* * *} \\
(0.0036)\end{array}$ \\
\hline Group 3 & $\begin{array}{l}0.0086^{\star *} \\
(0.0043)\end{array}$ \\
\hline Group 4 & $\begin{array}{l}0.008 \\
(0.0048)\end{array}$ \\
\hline
\end{tabular}


Table B2 (Continued)

\begin{tabular}{|c|c|}
\hline Dependent variable: log of labour cost & {$[1]$} \\
\hline \multicolumn{2}{|l|}{ Outside the region } \\
\hline Group 1 & $\begin{array}{l}-0.007 \\
(0.0296)\end{array}$ \\
\hline Group 2 & $\begin{array}{l}-0.005 \\
(0.0054)\end{array}$ \\
\hline Group 3 & $\begin{array}{l}0.002 \\
(0.0031)\end{array}$ \\
\hline Group 4 & $\begin{array}{c}-0.004 \\
(0.0058)\end{array}$ \\
\hline \multicolumn{2}{|l|}{ Domestic activity $_{t-1}$} \\
\hline Group 1 & $\begin{array}{c}-0.008 \\
(0.0185)\end{array}$ \\
\hline Group 2 & $\begin{array}{l}-0.005 \\
(0.0057)\end{array}$ \\
\hline Group 3 & $\begin{array}{l}0.005 \\
(0.0055)\end{array}$ \\
\hline Group 4 & $\begin{array}{l}0.001 \\
(0.0070)\end{array}$ \\
\hline \multicolumn{2}{|l|}{ Outside the region } \\
\hline Group 1 & $\begin{array}{c}-0.003 \\
(0.0213)\end{array}$ \\
\hline Group 2 & $\begin{array}{l}-0.001 \\
(0.0087)\end{array}$ \\
\hline Group 3 & $\begin{array}{l}-0.006 \\
(0.0062)\end{array}$ \\
\hline Group 4 & $\begin{array}{l}0.016^{*} \\
(0.0086)\end{array}$ \\
\hline Number of observations & 151567 \\
\hline Number of firms & 39753 \\
\hline Hansen ( $p$ value) & 0.99 \\
\hline $\operatorname{AR}(2)(p$ value $)$ & 0.95 \\
\hline Number of instruments & 70 \\
\hline
\end{tabular}

Regressions are two-step system -GMM estimator with firm-clustered and Windmeijer (2005)-corrected standard errors (in parenthesis). All estimations include time dummies. All firm-level characteristics (except age) are treated as potentially endogenous. First differences of potential endogenous variables (dated $t-4$ and longer) are used as instruments in the level equation and level values of potential endogenous variables (dated $t-4$ and longer) are used as instruments in the differenced equation

Coefficients significant at * $10 \% ; * * 5 \% ; * * * 1 \%$

\section{ABOUT THE AUTHORS}

Bettina Becker is a Lecturer in Innovation and Entrepreneurship at Aston Business School, UK. Her research interests lie in the areas of innovation and
$\mathrm{R} \& \mathrm{D}$, in particular innovation policy, social and inclusive innovation, entrepreneurship and SMEs, regions, and productivity.

Nigel Driffield is Professor of International Business and Deputy Vice Chancellor at Warwick University. His main research interest concerns the implications of international capital flows for both host and home economies, incorporating labour markets, knowledge flows and firm performance, and policy responses.

Sandra Lancheros is an applied economist with a special focus in the areas of international economics and industrial organization. Her main research interests are the causes and consequences of globalization on firms' performance. She pays particular attention to the activities of multinational companies, including their foreign direct investments, international trade, and their productivity-enhancing investments.

Jim H. Love is Professor of International Business at the University of Leeds. He previously held Chairs in international business and economics at Aston, Birmingham and Warwick Universities. His background is in applied microeconomics. His main research interests lie in the causes and effects of FDI, knowledge transfer within the MNE, and the links between innovation, exporting and productivity.

Open Access This article is licensed under a Creative Commons Attribution 4.0 International License, which permits use, sharing, adaptation, distribution and reproduction in any medium or format, as long as you give appropriate credit to the original author(s) and the source, provide a link to the Creative Commons licence, and indicate if changes were made. The images or other third party material in this article are included in the article's Creative Commons licence, unless indicated otherwise in a credit line to the material. If material is not included in the article's Creative Commons licence and your intended use is not permitted by statutory regulation or exceeds the permitted use, you will need to obtain permission directly from the copyright holder. To view a copy of this licence, visit http:// creativecommons.org/licenses/by/4.0/.

Publisher's Note Springer Nature remains neutral with regard to jurisdictional claims in published maps and institutional affiliations.

Accepted by Axèle Giroud, Area Editor, 18 March 2020. This article has been with the authors for two revisions. 